\section{La iglesia de Santo Domingo de La Iruela (Jaén). Excavación y Arqueología de la arquitectura}

\section{Church of Santo Domingo of La Iruela (Jaén). Excavation and Building Archaeology}

\author{
Vicente Salvatierra Cuenca* \\ Irene Montilla Torres \\ Mercedes Navarro Pérez \\ Universidad de Jaén
}

\begin{abstract}
Resumen
En este artículo presentamos los resultados de la intervención arqueológica efectuada en la iglesia de Santo Domingo de La Iruela (Jaén). Las excavaciones han permitido comprobar que antes del edificio actual, levantado en el siglo XVI, existió otro, que quizá también tuvo funciones religiosas. El análisis estratigráfico de los restos emergentes ha demostrado que el último edificio se construyó en un solo momento, aunque se emplearon materiales muy diferentes en la cabecera y en las naves, lo que abre la puerta a diversas interpretaciones. Por otra parte se ha comprobado que entre los siglos XVII y XVIII debió comenzar el deterioro del edificio. La última fase viene representada por su desacralización y uso como cementerio, acción que ha provocado graves daños en sus paramentos.
\end{abstract}

Palabras clave: Arquitectura renacentista; Adelantamiento de Cazorla; Arzobispado de Toledo; Andrés de Vandelvira; Francisco de los Cobos.

\begin{abstract}
In this article we present the results of the archaeological interventions carried out in the church of Santo Domingo in La Iruela, Jaén. The excavations revealed that, prior to the present building constructed in the $16^{\text {th }}$ century, there was another one that may also have had religious functions. The stratigraphic analysis permit knowing that the entire building was constructed at once, although the materials of the apse and the naves were very different; which allows for different interpretations. However, it has been proved that the deterioration of the building began between the seventeenth and the eighteenth century. The last stage is represented by the desecration and its use as a cemetery, which has caused important damages on the faces.
\end{abstract}

Key words: Renaissance architecture; Adelantamiento of Cazorla; Archbishopric of Toledo; Andrés de Vandelvira; Francisco de los Cobos.

\section{INTRODUCCIÓN}

La iglesia de Santo Domingo de La Iruela es un edificio considerado menor dentro de la arquitectura del renacimiento andaluz, en buena medida por la escasa calidad de parte de sus muros. A esa evaluación negativa, y a los escasos comentarios de que ha sido objeto por los especialistas en la arquitectura de la época, ha contribuido también de forma relevante su estado de ruina, iniciado ya en el siglo XIX, por lo que nunca fue posible analizar su cubierta ni buena parte de sus muros. También ha tenido importancia en esa marginación la falta de documentos sobre la misma, ya que ni en el archivo del arzobispado de Toledo, a cuya diócesis pertenecía, ni en el de la población en la que se encuentra, ni en el de Cazorla, capital del Adelantamiento, se han encontrado referencias a la misma. No obstante, desde el punto de vista histórico, tiene interés por estar en una zona donde trabajaron algunos de los principales maestros del siglo XVI, como Alonso de Covarrubias, Diego de Siloé, Andrés de Vandelvira o Rodrigo de Gibaja, y a que la construcción de la misma se ha relacionado con alguno de ellos o se han señalado sus influencias. Igualmente interesante es la incidencia que pudo tener en su construcción el juego de poder y prestigio entre varios poderosos señores de la época. Y en otro orden de cosas, los restos conservados presentan una serie de problemas de diverso tipo, como el hipotético reaprovechamiento de estructuras anteriores. Todas estas cuestiones hacían interesante su estudio y conservación. En 2009 se realizó una excavación arqueológica y el análisis de los paramentos con el fin de obtener datos para proceder a la consolidación de los restos existentes ${ }^{1}$. Esos resultados, unidos a un nuevo análisis de los pocos datos que es posible relacionar con la iglesia, han permitido aclarar la estructura y fases de la misma, así como profundizar en las circunstancias de su construcción. A estas cuestiones se dedica el presente estudio.

\section{SITUACIÓN E HISTORIA DE LA IRUELA (SIGLOS XII-XVI)}

El núcleo urbano del municipio de La Iruela se sitúa a un kilómetro al noreste de la conocida localidad jiennense de Cazorla. Está, por tanto, dentro del sistema montañoso compuesto por las sierras de Segura, Cazorla y Quesada, al este de la provincia de Jaén, y relativamente próximo a las fuentes del río Guadalquivir. Cartográficamente se localiza

\footnotetext{
${ }^{1}$ Los trabajos fueron financiados por la Excma. Diputación Provincial de Jaén. Se nos encargó la intervención arqueológica a propuesta del arquitecto responsable de la consolidación, Pedro Salmerón Escobar. 


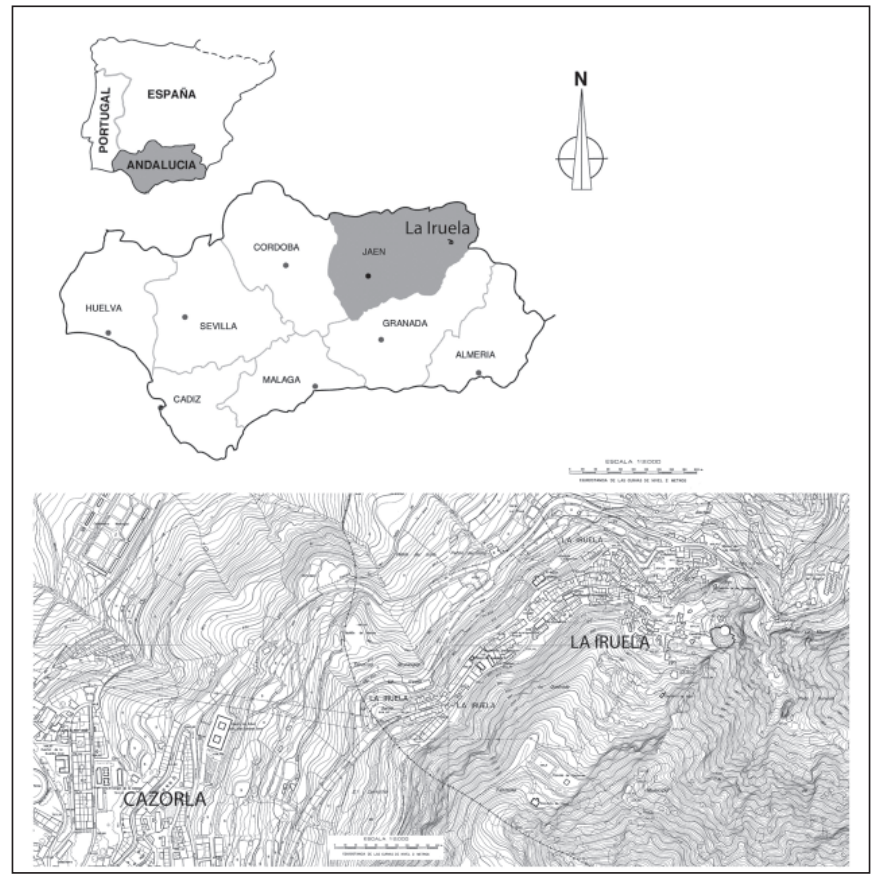

Fig. 1. Situación de La Iruela

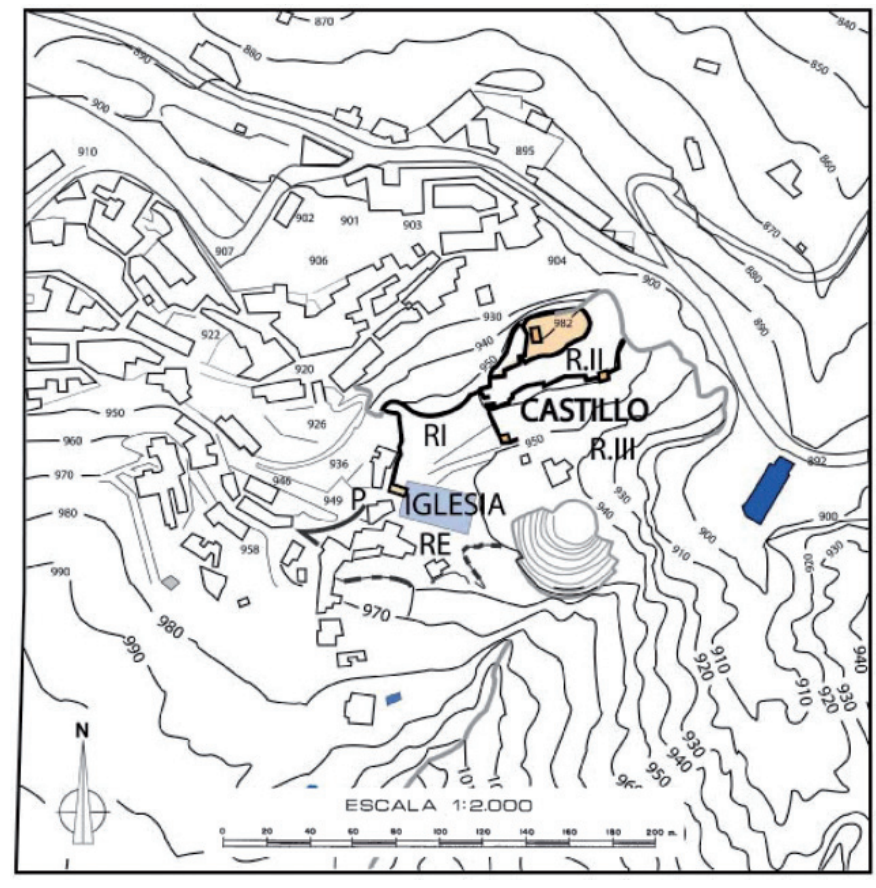

Fig. 2. La fortaleza de La Iruela. Situación relativa del castillo y la iglesia. Se señalan la plaza de armas (RI), el castillo (RII), el área de la aldea al sur (RIII) y la zona al occidente de la iglesia, posible ampliación de los siglos XV-XVI (RE)

que integran el sistema decorativo denominado «falso despiece de sillería» (Azuar 2005), sistema que tiene una cronología relativamente amplia, pero dentro del que esta variante en concreto es una de las mejor fechadas en el periodo almohade (Marquez, Gurriarán 2008:117-121). Junto a ello hay otros elementos, como la entidad y sección troncopiramidal de las torres, muy semejantes a dos de las situadas en el llano de Santa Catalina, en Orcera y fechadas en este periodo (Salvatierra et alii 2006:42-43) y la compleja estructura de la puerta, que apunta igualmente a una época tardía dentro de lo andalusí (Salvatierra 2006:75-76).

Por otro lado, es muy probable que la fortaleza se construyese como centro de un distrito castral (en el sentido descrito en Bazzana, Cressier, Guichard 1988:259292), que abarcaría gran parte de lo que luego será el Adelantamiento de Cazorla. Este tipo de castillos rurales podían realizarse directamente por el estado, o mediante la colaboración entre éste y las comunidades campesinas, ya que también eran un elemento fundamental para su protección. En principio, los elementos señalados apuntan a la presencia de un maestro de obras de alto nivel, con conocimientos de fortificación y, por tanto, a la participación del Estado. Rafael Azuar (Azuar 2005) considera que un buen número de las fortificaciones almohades fueron impulsadas por el califa Abu Yusuf Ya'qub al-Mansur (1184-1199) y su sucesor Abu 'Abd Allah al-Nasir (11991213), con el fin de reforzar la frontera de al-Andalus 


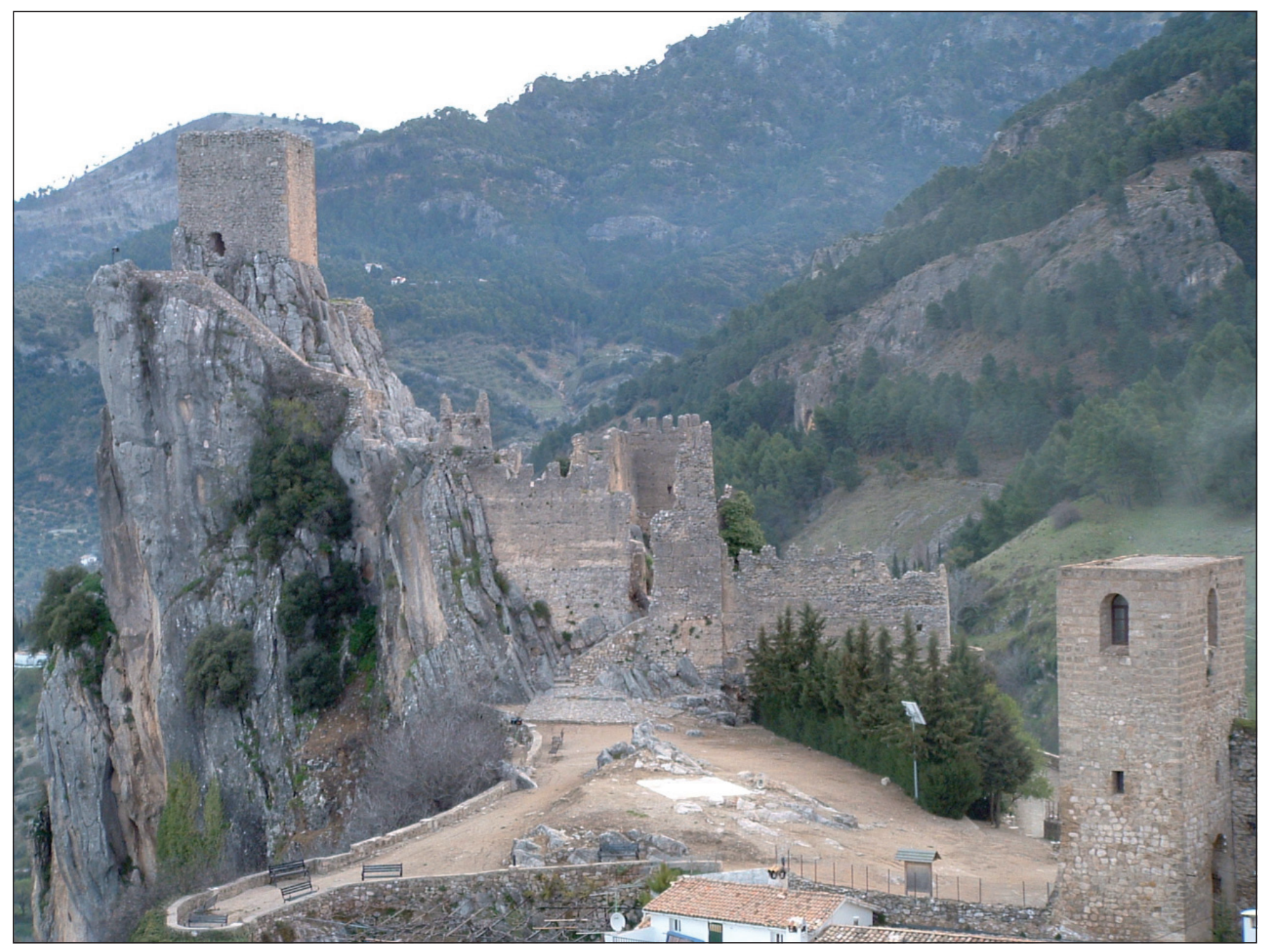

Fig. 3. El castillo desde el oeste. La plaza de armas en primer plano

frente a la ofensiva de portugueses, castellanos y aragoneses. Es posible que esta fortificación formase parte de dicho programa.

El promontorio donde se ubica el castillo descendía por el sur hacia una vaguada que lo separaba de las estribaciones del cerro Escribano. En base a la observación del espacio y a las excavaciones realizadas, cabe deducir que por esta última zona se extendió una aldea islámica, establecida en fecha incierta, pero quizá al mismo tiempo que el castillo. El lugar se escogió por estar protegido, incluso visualmente, por las alturas situadas al sur y al norte. La zona constituiría así mismo el núcleo de la primera ocupación cristiana. En este sentido, las menciones más antiguas recogidas en las fuentes escritas, tanto del territorio como sobre la población, son de la época de la conquista castellana. En 1231 Fernando III concedió mediante privilegio rodado el señorío de la villa de Quesada, aún por conquistar, a la iglesia de Santa María de
Toledo, para que en su nombre la tuviera el arzobispo primado de Toledo Don Rodrigo Ximenez de Rada ${ }^{3}$. Pocos meses después el arzobispo se lanzó a la conquista de Quesada y de todas las localidades próximas, incluida $\mathrm{La}$ Iruela (Ximenez de Rada 1989:349; Primera Crónica General 1977:725), apoderándose del núcleo central de lo que posteriormente constituirá el señorío del Adelantamiento de Cazorla.

Aparte de las crónicas, se conservan algunos documentos que hacen referencia a La Iruela a lo largo de los siglos XIII y XV, aunque los mismos aluden principalmente a diversos aspectos sobre la organización y evolución del Adelantamiento, sin que haya referencias a obras realizadas en la población ${ }^{4}$. Sintéticamente cabe señalar que, después

${ }^{3}$ Archivo Catedral de Toledo X-9-E-1-2. Carriazo 1975: XLV-XLVI, doc. 1; González 1983, doc. 295.

${ }^{4}$ Dichos documentos se localizan fundamentalmente en el Archivo Municipal de Quesada, en el Archivo de la Catedral de Toledo, en el Archivo de la Diócesis de 


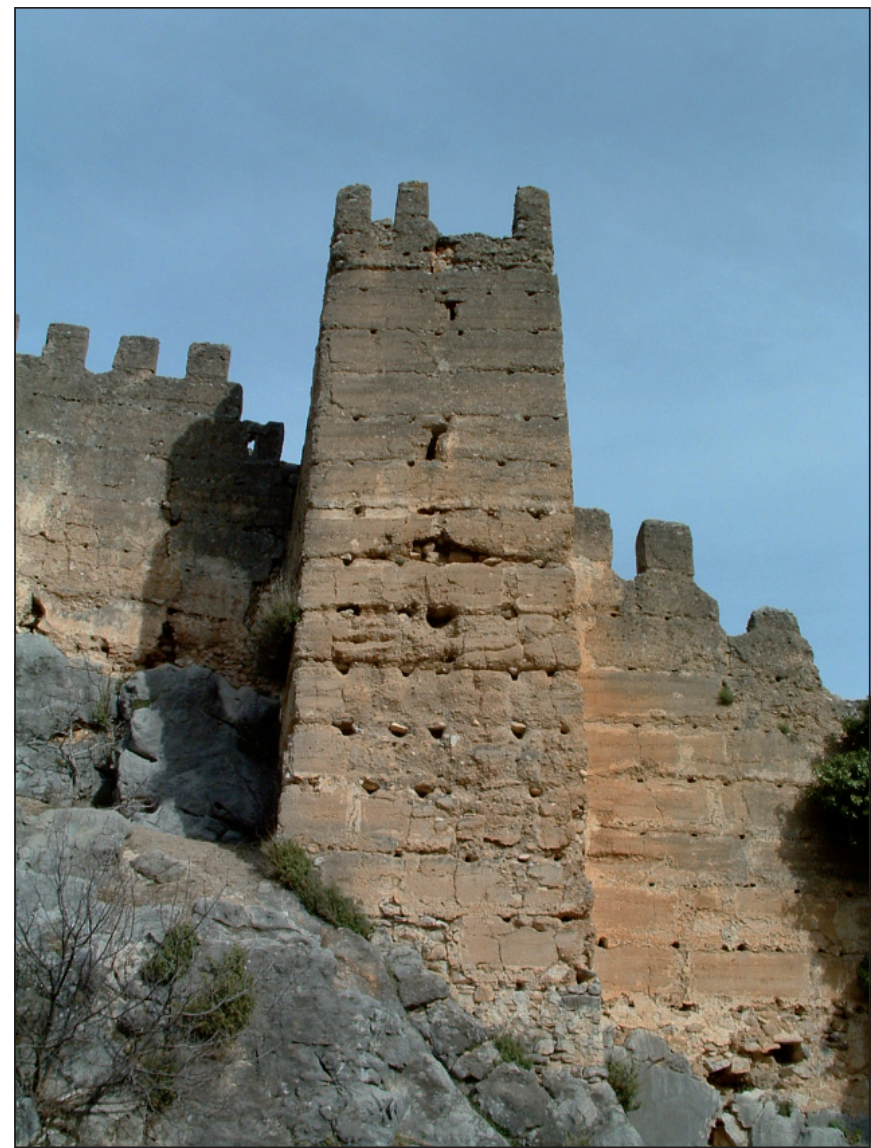

Fig. 4. Torre y muralla entre los sectores II y III. Se aprecia el despiece de sillares

de la conquista, todas las poblaciones mantuvieron inicialmente la igualdad de la que habían gozado en época islámica, aunque después los arzobispos impusieron una jerarquización entre ellas. No obstante, Rivera Recio (1948:5) consideró que ya Don Rodrigo había convertido en 1233 a Cazorla en capital del Adelantamiento por razones de seguridad fronteriza. El infante Don Sancho de Castilla, arzobispo de Toledo entre 1251-1261, reorganizaría el señorío en torno a las villas de Cazorla, Quesada e Iznatoraf, y en concreto, adscribió el 23 de noviembre de 1256 a Cazorla diversas aldeas, entre ellas La Iruela (García Guzmán 1985:47). Juan de Mata Carriazo (1973:L-LII) consideró que ésta era la localidad que en los documentos del siglo XIII del arzobispado de Toledo aparece bajo los nombres de El Eruela, Areola, Theruela y Arcola, y que posiblemente éstas son las distintas interpretaciones escritas que los castellanos hicieron de su nombre árabe, que sigue siendo desconocido. El papel de Cazorla se reforzó en

Toledo, en el Archivo Histórico Nacional y en el Archivo General de Simancas. A parte de algunas ediciones parciales, todos ellos han sido recogidos por M. ${ }^{\text {a }}$ del Mar García Guzmán (1991).
1333, ya que al pasar Quesada a depender de Úbeda, se convirtió realmente en capital del Adelantamiento.

Todo este proceso tuvo que repercutir en las posibilidades de desarrollo de las demás poblaciones del señorío, en especial de una tan próxima como La Iruela, hasta el punto de que su fortaleza probablemente quedó casi abandonada al construirse los castillos que rodean Cazor$1 a^{5}$. La Iruela recuperará su «autonomía» en 1378 , cuando el arzobispo Don Pedro Tenorio le reconozca el privilegio de villazgo como conclusión de un largo enfrentamiento entre la localidad y Cazorla (García Guzmán 1985:339$\left.344^{6}\right)$. Es muy posible que sea a partir de ese momento, pudiendo ya disponer de sus propios recursos, cuando además de reparaciones en el castillo, se levante la hoy denominada Torre del Picacho en la cima de la peña. Y progresivamente se llevará a cabo la construcción de distintas obras de gran carga simbólica que reflejarán el nuevo estatus de la población, como la primera iglesia de la localidad, la muralla que cerraba la misma, o la torrepuerta que aún hoy permite el paso a la plaza de armas.

La primera referencia que tenemos a una iglesia en La Iruela es de 1488, cuando el cardenal Don Pedro González de Mendoza, arzobispo de Toledo, ante la ausencia del prior de la iglesia, autorizó al concejo de la villa a que pusiera un capellán (García Guzmán 1991, doc. 279). Es posible que ésta corresponda a los restos localizados en las excavaciones efectuadas bajo la iglesia de Santo Domingo. Se trata de un edificio con muros realizados con mampostería encofrada, con piedras de mediano tamaño dispuestas irregularmente, lo que se aprecia en la cara exterior del paramento, pese al grueso enfoscado que la cubre, que carece de homogeneidad, lo que a su vez sugiere un largo periodo de uso y reparación, todo lo cual da una apariencia de tosquedad y pobreza que contrasta con la calidad de buena parte de la fortificación. Se han estudiado dos muros, el primero, con dirección norte-sur, tiene $5,00 \mathrm{~m}$ de longitud, más de $0,80 \mathrm{~m}$ de anchura y conserva $1,50 \mathrm{~m}$ de altura, de los que $0,40 \mathrm{~m}$, situados bajo el más antiguo de los dos pavimentos de argamasa que se le adosan, corresponden a la cimentación, que se apoya en una zapata de piedras desordenadas (fig. 5). El segundo, con orientación este-oeste, formaría ángulo recto con el primero. Casi completamente destruido en anchura por una sepultura de época moderna, sólo conserva $0,30 \mathrm{~m}$ de altura, y al

\footnotetext{
${ }^{5}$ Estos castillos, La Yedra y Cinco Esquinas, nunca han sido objeto de estudios detallados, ni de excavaciones. Aunque pudieran tener una fase antigua, como en ocasiones se ha señalado, no hay duda de que las principales obras son del siglo XIV, como propuso J. Eslava (1999:324-331).

${ }^{6}$ Archivo de la Diócesis de Toledo. Adelantamiento de Cazorla, leg. 1, no 2.
} 


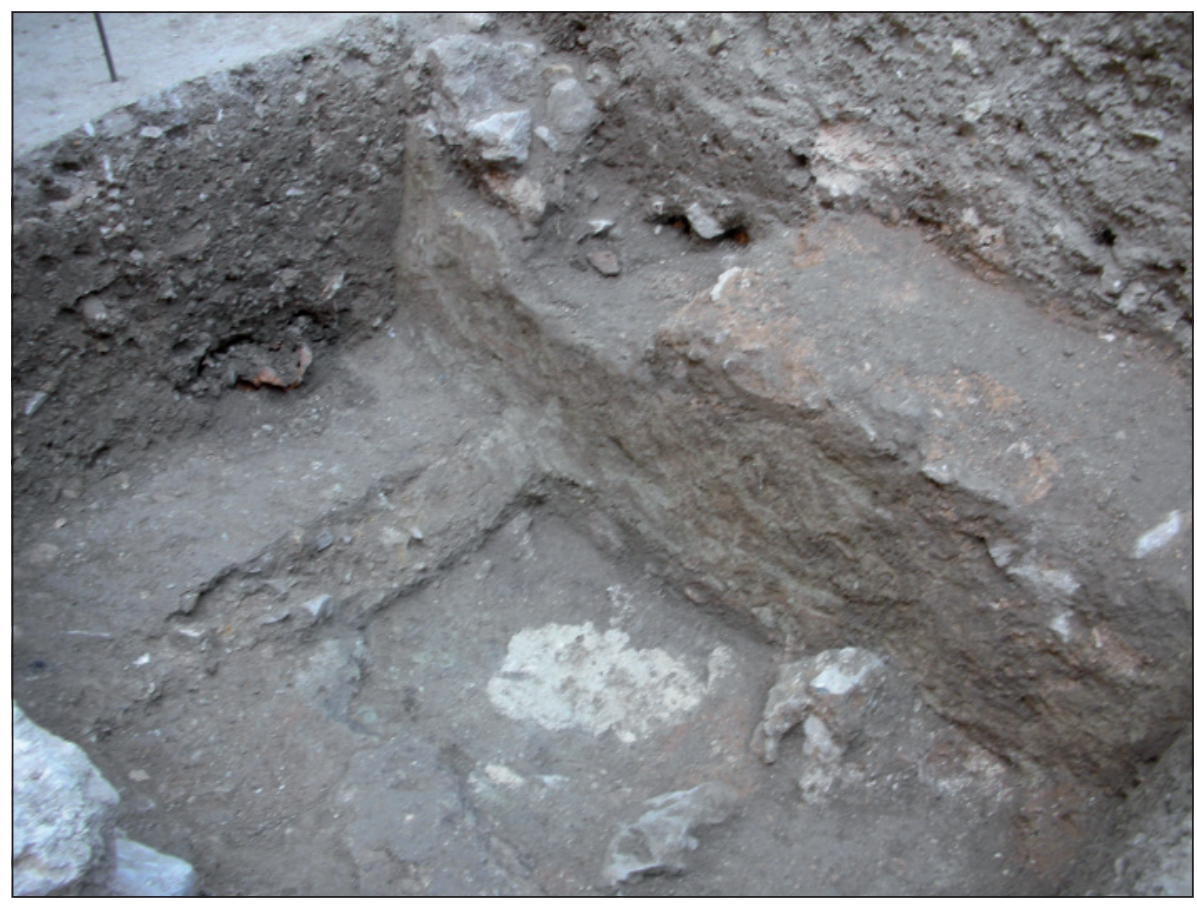

Fig. 5. Muro de tapial del primitivo edificio

mismo se adosan otros dos pavimentos similares a los anteriores. Los dos conjuntos están separados unos 2,00 m por la base de un gran pilar y otros elementos correspondientes a los cimientos de la iglesia renacentista (fig. 6). La pequeña distancia entre los muros excavados permite considerar que se trata del mismo edificio, del que en conjunto se ha explorado una superficie de 5,00 × 4,00 m, aunque por el espacio disponible debía ser bastante mayor. Los pavimentos más antiguos de cada zona están a una altura similar. Pero los otros presentan una diferencia de $0,20 \mathrm{~m}$ entre ellos, lo que parece implicar que en un momento dado existió un pequeño escalón entre ambos espacios. Aunque el edificio se sitúa sobre niveles almohades, con los datos disponibles no es posible establecer la cronología del mismo, ya que podría ser tanto de época almohade como de primera época cristiana. No obstante los rasgos de poco cuidado y tosquedad de la construcción a los que hemos hecho referencia serían un elemento que apoyaría su cronología castellana (Gurriarán, Sáez 2003:586-587, nota79). Tampoco es posible determinar el tipo de edificio de que se trata, aunque su aparente amplitud, los cuidados pavimentos, la ausencia de material de uso cotidiano (cerámica, huesos...) y su ubicación, permiten formular la hipótesis de su función religiosa. En conclusión, aunque no puede descartarse que la población andalusí construyera una mezquita que fue convertida en iglesia tras la conquista castellana, elementos como los pavimentos alejan a este edificio de otras mezquitas rurales

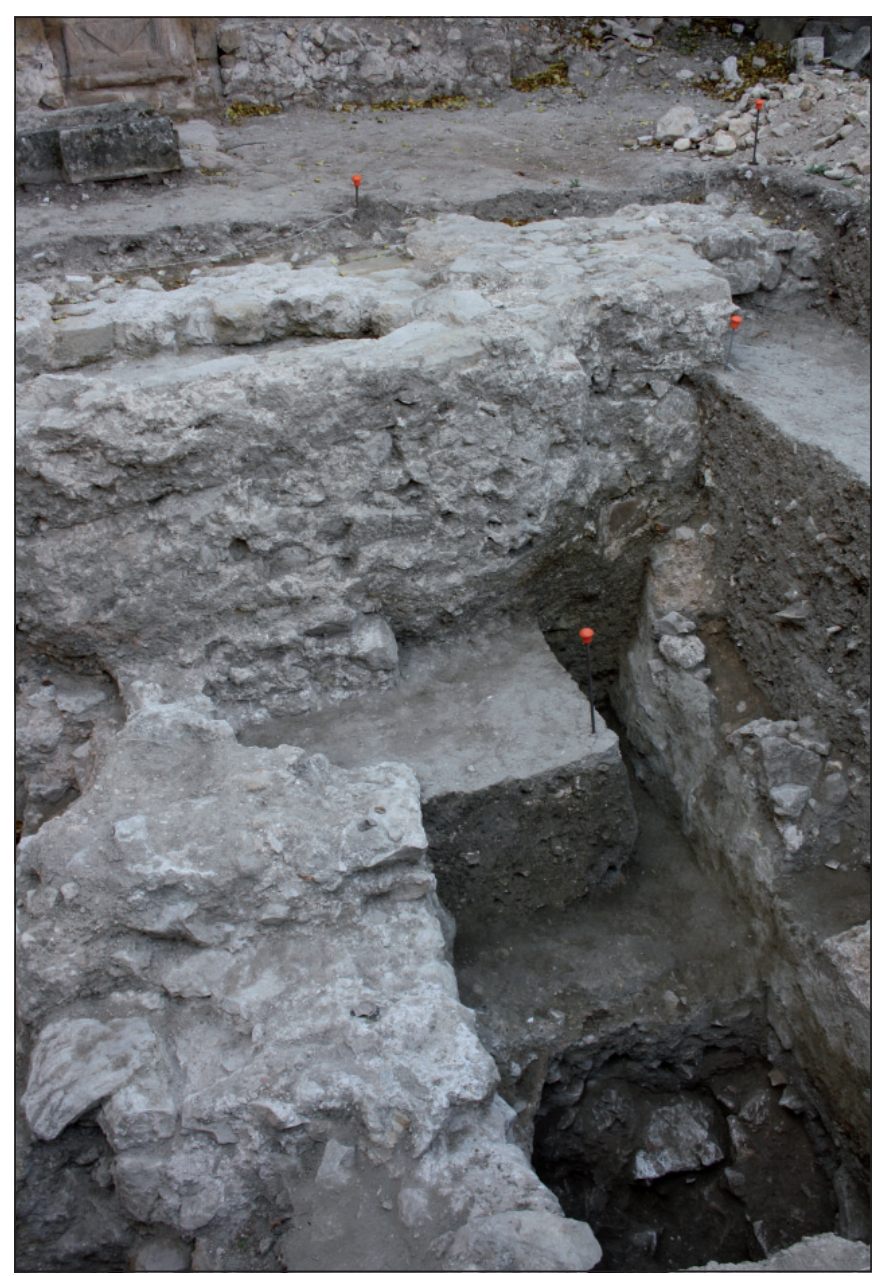

Fig. 6. Base del pilar del crucero. A la derecha muro de tapial del edificio primitivo 
de pequeñas poblaciones, por lo que parece más probable que se trate de un iglesia construida cuando la población castellana obtuvo su nuevo estatuto de villazgo.

En el siglo XVI, terminada la conquista de Granada, se producirá un notable crecimiento económico en el antiguo reino nazarí, como resultado de la intensa repoblación, impulsada tanto por la corona, como por la nobleza, que potenciaron la riqueza de estos territorios. Ese crecimiento se extenderá también al Alto Guadalquivir, territorio que hasta es momento había sido frontera, por lo que su crecimiento había estado contenido. Las poblaciones del Adelantamiento de Cazorla compartirán este desarrollo, que se advierte en su crecimiento poblacional. Concretamente La Iruela pasó de 517 vecinos en 1528 a 741 en 1561, y a 932 en 1595 (Moliniè-Bertrand 1977:9-10, cuadro 1), crecimiento que se tradujo, entre otros elementos, en el desarrollo urbano y en la construcción de una serie de edificios relevantes. En concreto se construirá una puerta de acceso al antiguo núcleo de la población, pero sobre todo se producirá el primer ensanche urbano, por el que la misma se extendió hacia el suroeste, siguiendo las curvas de nivel a lo largo de dos ejes formados por las calles Corredera y San Antón, que confluían en una plaza, hoy denominada de La Constitución. Este ensanche rompió con la estructura puntual, amurallada, que había caracterizado a la población durante la Edad Media (Fernández Serdán 2001:306-307). En el extremo de los nuevos ejes mencionados, junto a la plaza actual, se levantó a partir de 1572 el edificio del pósito, cuyas trazas se atribuyen a Andrés de Vandelvira (Gila, Ruiz 1992:100-101; Montero et alii. 1991:237-238; Galera 2000a:144-145; Galera 2000b:301).

Al mismo tiempo debieron construirse dos nuevas iglesias, aunque la primera referencia conocida a las mismas es la mención a su existencia que en 1626 realiza Ximenes Paton (1983:239) que ni siquiera las identifica; en 1646 Rus Puerta (1998:146) reitera que había dos parroquias y especifica que eran la iglesia Mayor de Santo Domingo y la de La Concepción. Aunque las citadas referencias no aportan datos sobre su ubicación, cabe identificar la primera con la que es objeto de este estudio y que según algunos especialistas en historia del arte debió construirse a partir de los años treinta del siglo XVI (Chueca 1971:305; Galera 2000b:300; Moreno et alii 2005:488). La segunda se situó al este del edificio del pósito y sería sustituida en 1956 por la iglesia actual, sin que nunca se realizara un estudio artístico o arqueológico de la misma, ni tampoco hemos localizado fotografías, lo que impide efectuar cualquier análisis sobre la misma. No obstante, por su situación en el ensanche de la población, y el hecho de ser citada ya en 1626, cabe suponer que se levantaría también en el siglo $\mathrm{XVI}^{7}$, aunque no sabemos cual fue su relación temporal con la primera.

Este proceso de crecimiento y sacralización de la localidad sería impulsado en parte por los arzobispos de Toledo y, en parte, por D. Francisco de los Cobos, secretario de Carlos V (1516-1547) y sus sucesores. El primero logró que en 1534 el cardenal D. Juan Pardo de Tavera le nombrase Adelantado de Cazorla ${ }^{8}$. En 1539 obtuvo una bula papal, que el emperador confirmó en 1541, por la que el señorío le era entregado como «Gracia bajo censo" a él y a sus herederos. A la muerte de Don Juan Tavera trató de que el nuevo arzobispo Don Juan Martínez Siliceo confirmase la cesión, pero este se negó, pese a las presiones del propio emperador, quién finalmente dejó el tema en manos de los tribunales. El largo pleito sería continuado por los sucesivos arzobispos, y por los marqueses de Camarasa, herederos de Don Francisco de los Cobos, hasta concluir con un acuerdo por el que en 1606 la iglesia recuperó el territorio (Keniston 1980:153-155).

\section{LA IGLESIA DE SANTO DOMINGO. DESCRIPCIÓN Y EXCAVACIONES}

La iglesia es un rectángulo ligeramente irregular, que ocupa un área aproximada de unos $650 \mathrm{~m}^{2}$ (fig. 7), se organiza en una planta de salón típicamente renacentista, organizada en tres naves, la central de doble anchura que las laterales y testero plano. Al este, la cabecera y los laterales hasta los extremos del crucero están realizados con sillares bien trabajados en la planta baja y sillarejo de toba en la superior, mientras que en el resto, donde sólo se conserva la planta baja, es de mampostería irregular con piedras de mediano tamaño, lo que hace a esos paramentos mucho más ligeros. Por el desnivel del terreno, en esta última zona la roca está casi en superficie, por lo que la cimentación es prácticamente inexistente. Por el contrario, al este la base geológica baja más de tres metros, la excavación del

\footnotetext{
${ }^{7}$ Al tratarse de edificios religiosos pertenecientes al arzobispado de Toledo, cabría pensar que en el Archivo de la Catedral de Toledo o en el de la Diócesis de Toledo debería haber documentación sobre la construcción de estas iglesias. Sin embargo ninguno de los estudiosos que ha tocado el tema ha podido localizar hasta ahora datos sobre las mismas, pese a que se han buscado, dado el interés que despiertan en relación a la posible intervención en la primera de Andrés de Vandelvira.

${ }^{8}$ El nombramiento de Adelantado de Cazorla era una potestad del arzobispo de Toledo, y el nombramiento era casi vitalicio, aunque cesaban cuando moría quien los había nombrado. Parece que Don Francisco de los Cobos aprovechó la muerte del arzobispo Don Alonso de Fonseca (1523-1534), para llegar a un acuerdo con el arzobispo de Santiago, Don Juan Tavera (1534-1545), ofreciéndole emplear su influencia cerca del emperador, para que este lo designara nuevo arzobispo de Toledo, a cambio de ser después nombrado por él Adelantado de Cazorla. Ambos cumplieron sus compromisos.
} 


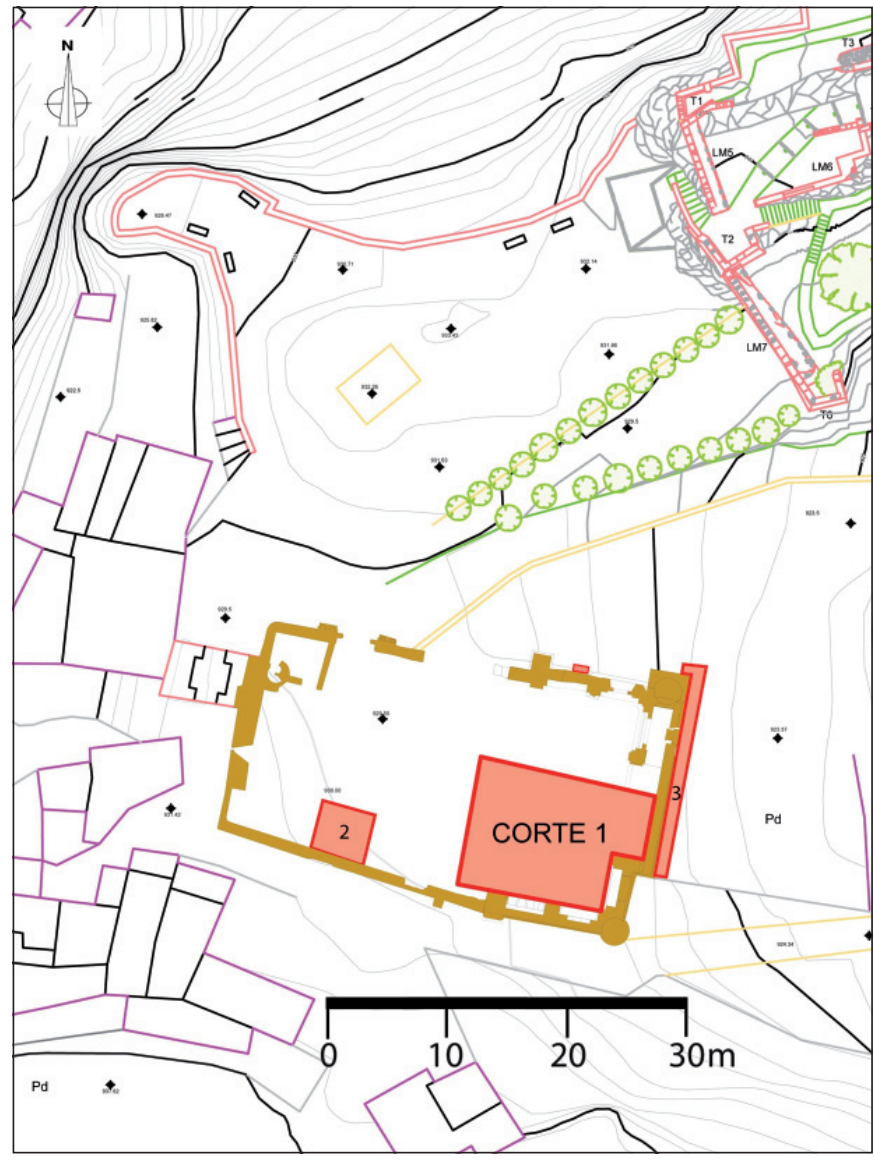

Fig. 7. Plano de la Iglesia

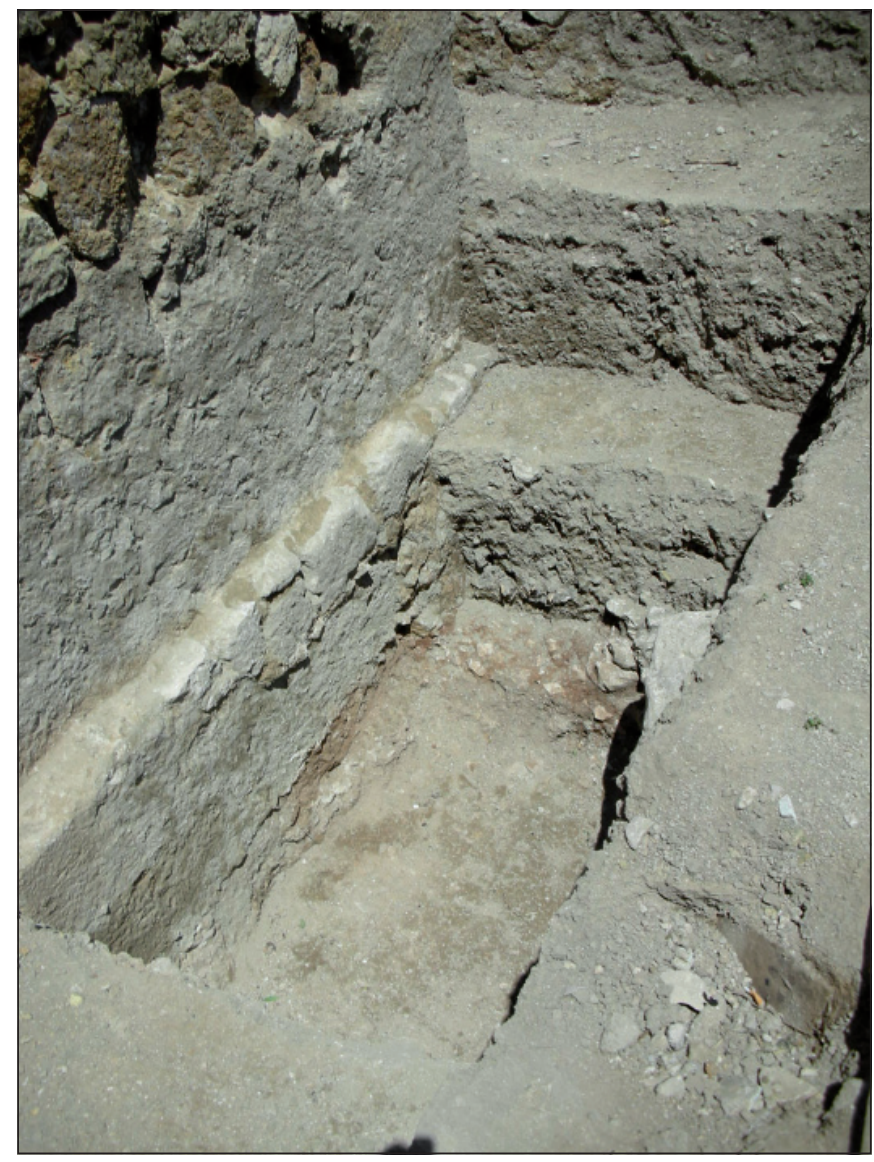

Fig. 8. Corte 3, en el extremo derecho se advierten restos de la cimentación, rota por enterramientos

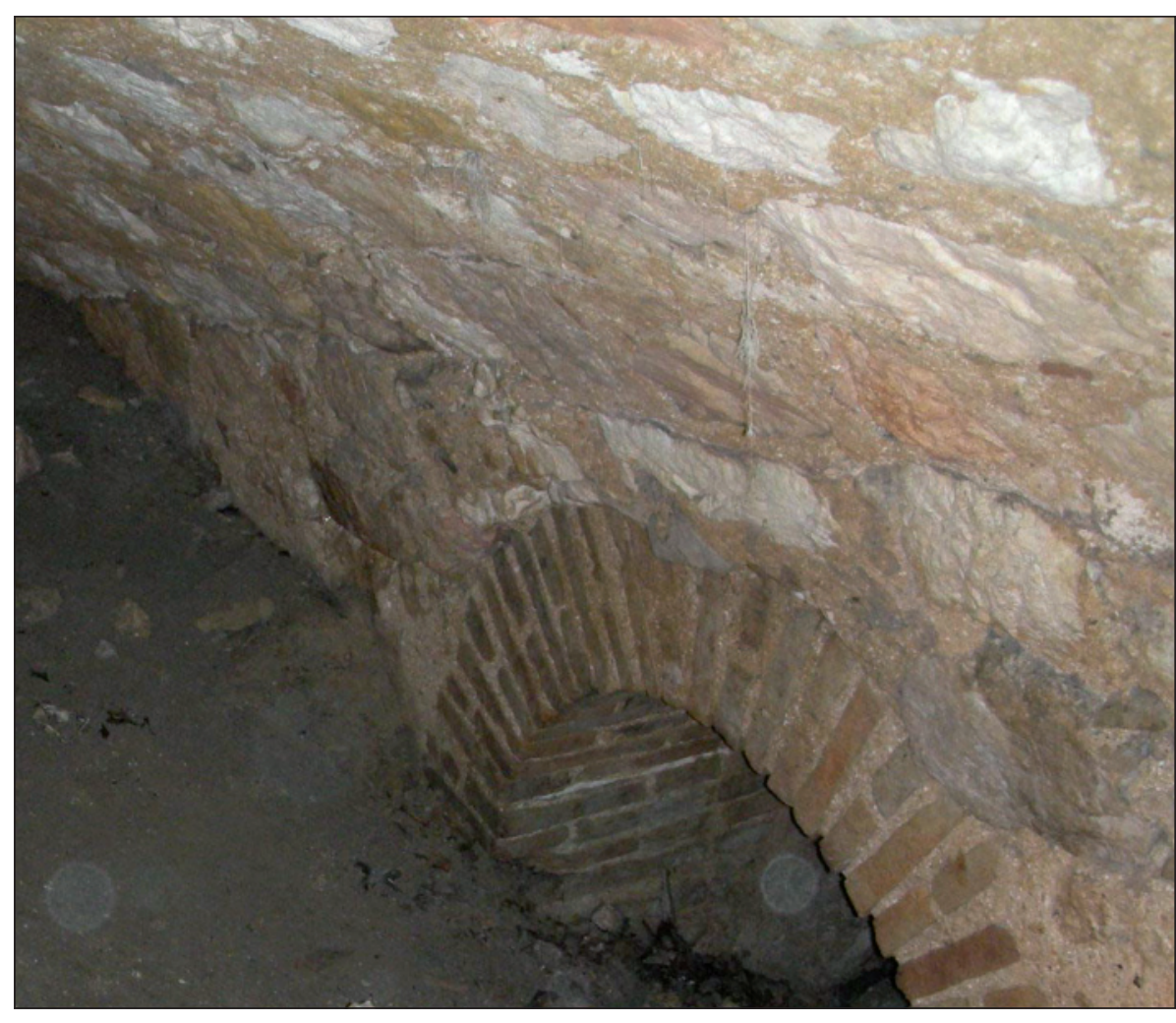

Fig. 9. Pasillo interior de la cripta hacia el oeste 


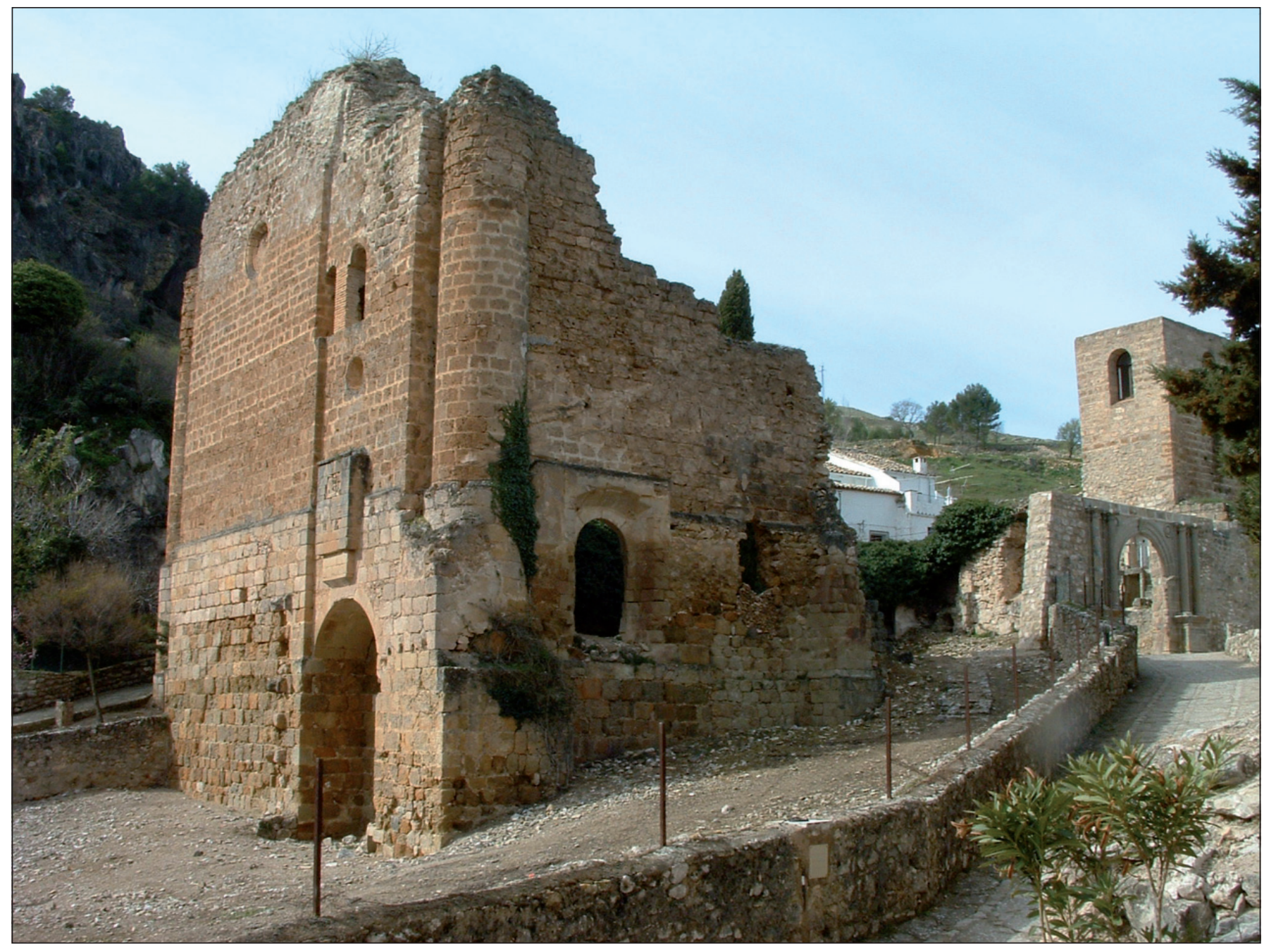

Fig. 10. La iglesia desde el noreste

corte 3, al exterior de la cabecera, permitió localizar una potente cimentación, que probablemente se extiende por los lados, hasta los extremos del crucero, con un primer nivel constituido por un mortero de gran dureza, formado por piedras de pequeño tamaño y argamasa, de un metro de potencia y gran anchura, aunque fue afectado por los enterramientos posteriores (fig. 8).

Así mismo, esta mayor profundidad se aprovechó para construir los grandes pilares del crucero, habiéndose localizado en el corte 1 el del lado sur, junto a los estribos que lo unían con los pilares de los lados norte y oeste. Al este del pilar, bajo el crucero, con orientación norte-sur se construyó una gran cripta de enterramiento, abovedada, con unos $2.50 \mathrm{~m}$ de altura, realizada con mampostería. Del interior de la misma parte un corredor con muros y bóveda de ladrillo hoy casi completamente cegado (fig. 9) que, con dirección este y cierta inclinación, quizá conduce a otra cripta bajo el presbiterio, y en cualquier caso a un gran vano situado en el ángulo noreste, hoy tapiado, que sería el acceso exterior a los espacios subterráneos. Además, en el extremo del crucero sur se construyó un panteón familiar, con orientación este-oeste, cuya lápida, que se ha conservado, nos informa de que el espacio fue adquirido en 1624, aunque a los herederos no se les reconoció la propiedad hasta 1797, lo que arroja dudas acerca de cuándo se construyó y empezó a utilizarse. Todos estos elementos destruyeron gran parte de un edificio anterior, como ya hemos señalado, y cuyos pavimentos fueron también afectados por enterramientos individuales.

La cabecera está enmarcada por sendos "torreones» circulares. Por el exterior (fig. 10), al noreste, se refleja ligeramente la estructura tripartita de las naves de la iglesia. Los sectores sur y central son muy homogéneos, animado el último sólo por un rosetón en altura, que posteriormente fue cegado. El lado norte, por el contrario, muestra una notable complejidad. En la planta baja, a un nivel situado en 


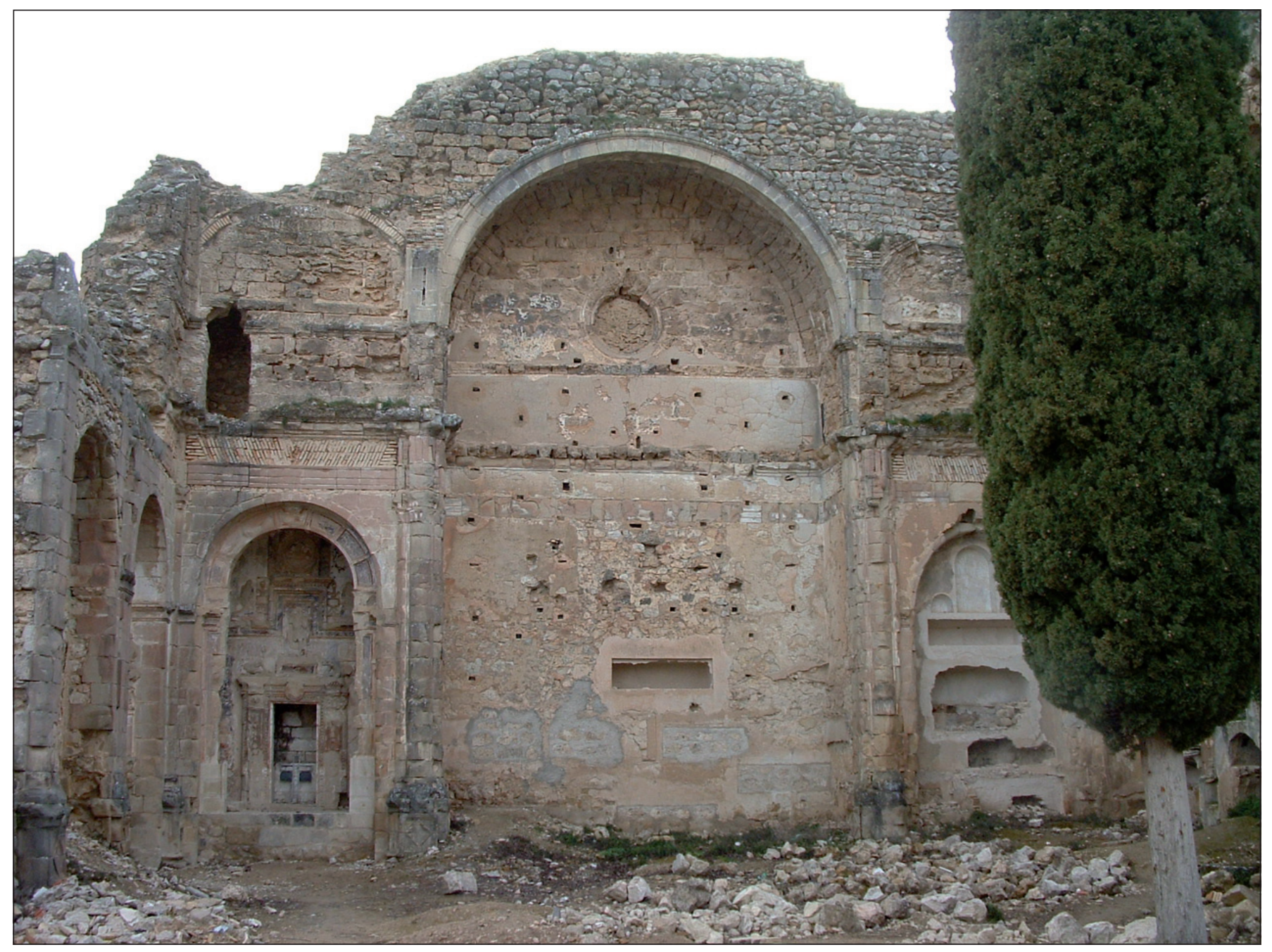

Fig. 11. Cabecera interior de la iglesia

gran parte por debajo del pavimento del presbiterio, cubierto por un arco está el gran vano que debe comunicar con la cripta subterránea, aunque por el tipo de sillar que hoy lo cierra es posible que nunca llegase a estar abierto; en el lateral izquierdo (sur) sobresalen una serie de sillares alineados de arriba abajo, y en el lado derecho y algo por encima del arco se aprecian una serie de cajas de vigas, todo lo cual apunta a que quizá estaba prevista la construcción de otro cuerpo, que no se realizó. El arco estaba coronado por un elemento saliente que quizá pretendía simular cierto nivel de fortificación. Por encima de este conjunto se localiza otro rosetón, y en la parte superior se abre una ventana geminada, desplazada al lado sur. Posiblemente los dos últimos elementos daban luz respectivamente a una corta escalera, y a una habitación construida en el interior del muro.

Por el interior del templo la estructura tripartita de la cabecera es muy acusada, y se relaciona con las naves (fig. 11). El espacio central, que corresponde al presbiterio, tiene una anchura doble que los laterales, y está cubierto con un gran arco triunfal. En el muro, cerca de la coronación, estaba el primer rosetón mencionado. Los espacios laterales corresponden a sendas capillas de estructura desigual. La del lado norte (fig. 12), elevada respecto al pavimento, presenta elementos estructurales en profundidad, y quizá contuviera el reservado eucarístico frecuente en el siglo XVI, realzado por una portada decorada de estilo rococó, que aparece quemada. En la parte superior del paramento, junto al ángulo noreste, se encuentra una puerta que da paso a la escalera de acceso a la habitación superior. La capilla del lado sur está desfigurada por la construcción de un panteón, con varios nichos superpuestos coronados por el espacio para una placa funeraria, que debió realizarse entre los siglos XIX y XX. Por debajo de la cornisa de toda la cabecera y de los laterales correspondientes al crucero corre un friso para alojar la decoración, que en su mayor parte ha desaparecido. 


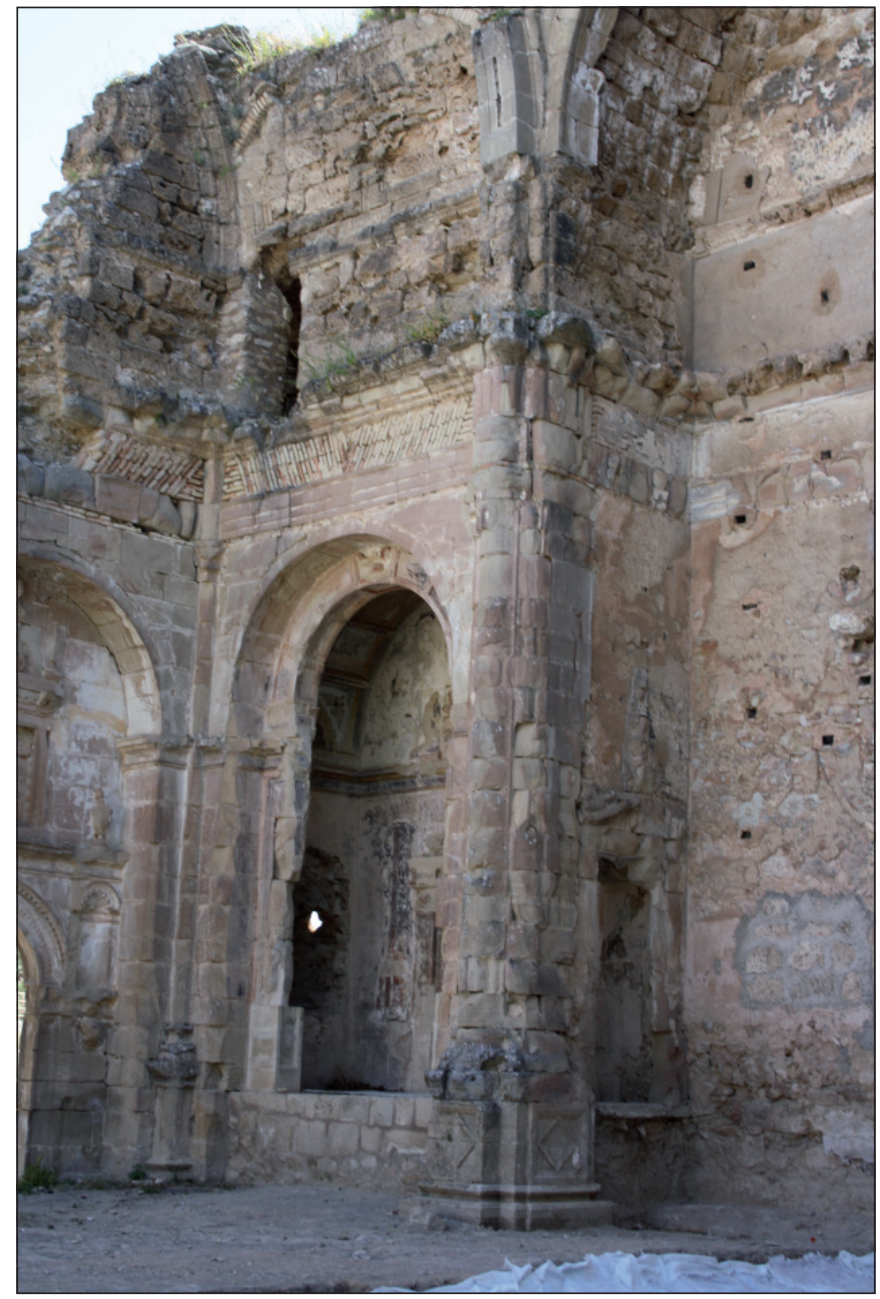

Fig. 12. Capilla del lado norte

El crucero estaba constituido por el tramo final de las naves. Sus extremos al norte y sur se realizaron con los mismos materiales que la cabecera; estaban separados de las naves por sendas pilastras adosadas, que resaltan claramente de los respectivos paramentos, y que se corresponden con contrafuertes al exterior, los únicos con que parece que contó el edificio. En altura, la anchura del crucero en el lado sur queda resaltada por un elemento abarcante, un gran arco que la engloba (fig. 13), empleado por Diego de Siloé en la catedral de Granada, y en el Alto Guadalquivir por Andrés de Vandelvira. Sin embargo, en el tímpano que se genera en la parte superior de este elemento se abren tres huecos que iluminaban el templo, sistema procedente de la tradición castellana, por lo que algunos especialistas los relacionan con la presencia de Rodrigo de Gibaja. En la planta inferior, el espacio se divide en dos capillas, separadas por una pilastra, que apenas resalta del muro, coronada por una hornacina. En dichas capillas, aprovechando la anchura de sus muros, se construyeron nichos del cemen- terio moderno. Todo el resto del muro sur se realizó con mampostería irregular, y por el interior se introdujeron también numerosos nichos de enterramiento que afectaron al paramento exterior, requiriendo numerosas reparaciones. El crucero norte (fig. 14) debía tener una disposición semejante, pero la parte superior ha desaparecido en gran parte, aunque en la inferior las capillas conservan más elementos originales. La de la izquierda (oeste) ofrece en el cierre del fondo, y entre el arco y el friso, distintos aparejos de mampostería irregular, que demuestran que sufrió diversos cambios a lo largo del tiempo. La capilla derecha se organiza como una puerta, que al interior de la iglesia presenta un arco con nichos laterales, y por encima de la clave una gran metopa muy deteriorada, mientras que al exterior resalta su estructura abocinada. Estas estructuras parecen implicar que estaba previsto que ambas capillas fueran los accesos a sendas estancias que nunca llegaron a levantarse. Parte del resto del paramento de este lado ha desaparecido, y sólo subsisten restauraciones del siglo XX en el extremo noroeste.

La iglesia contó con dos puertas situadas respectivamente en los lados norte y sur. El corte 2 ha permitido

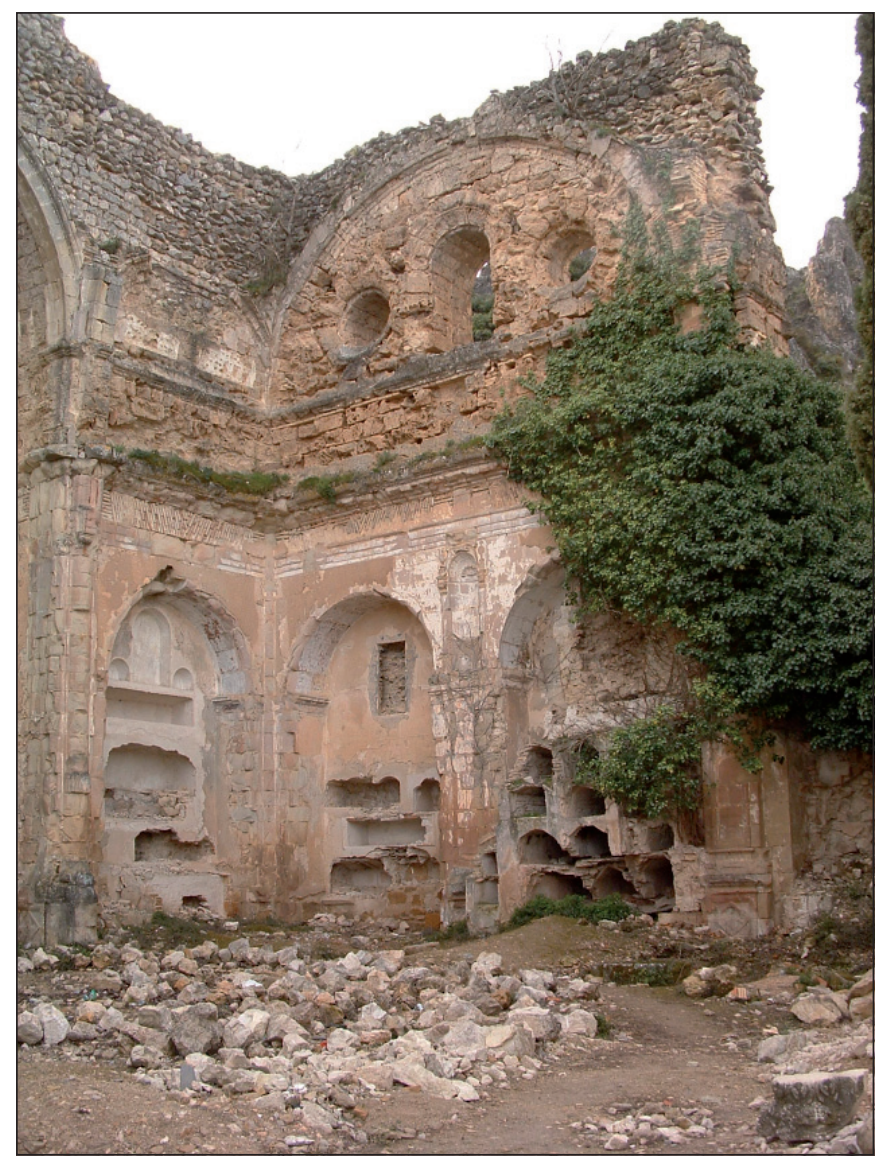

Fig. 13. Paramento de cierre del crucero sur 


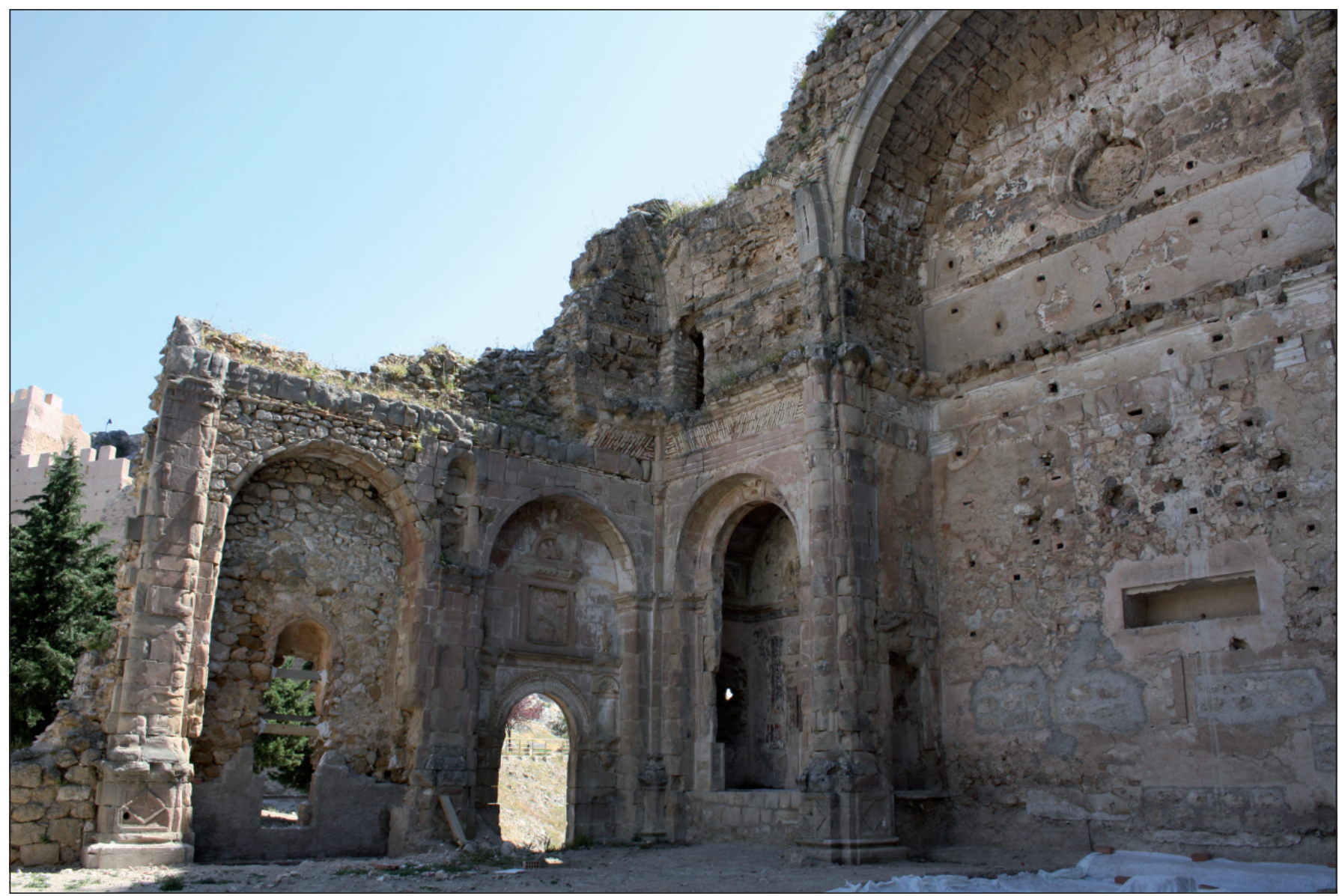

Fig. 14. Crucero norte

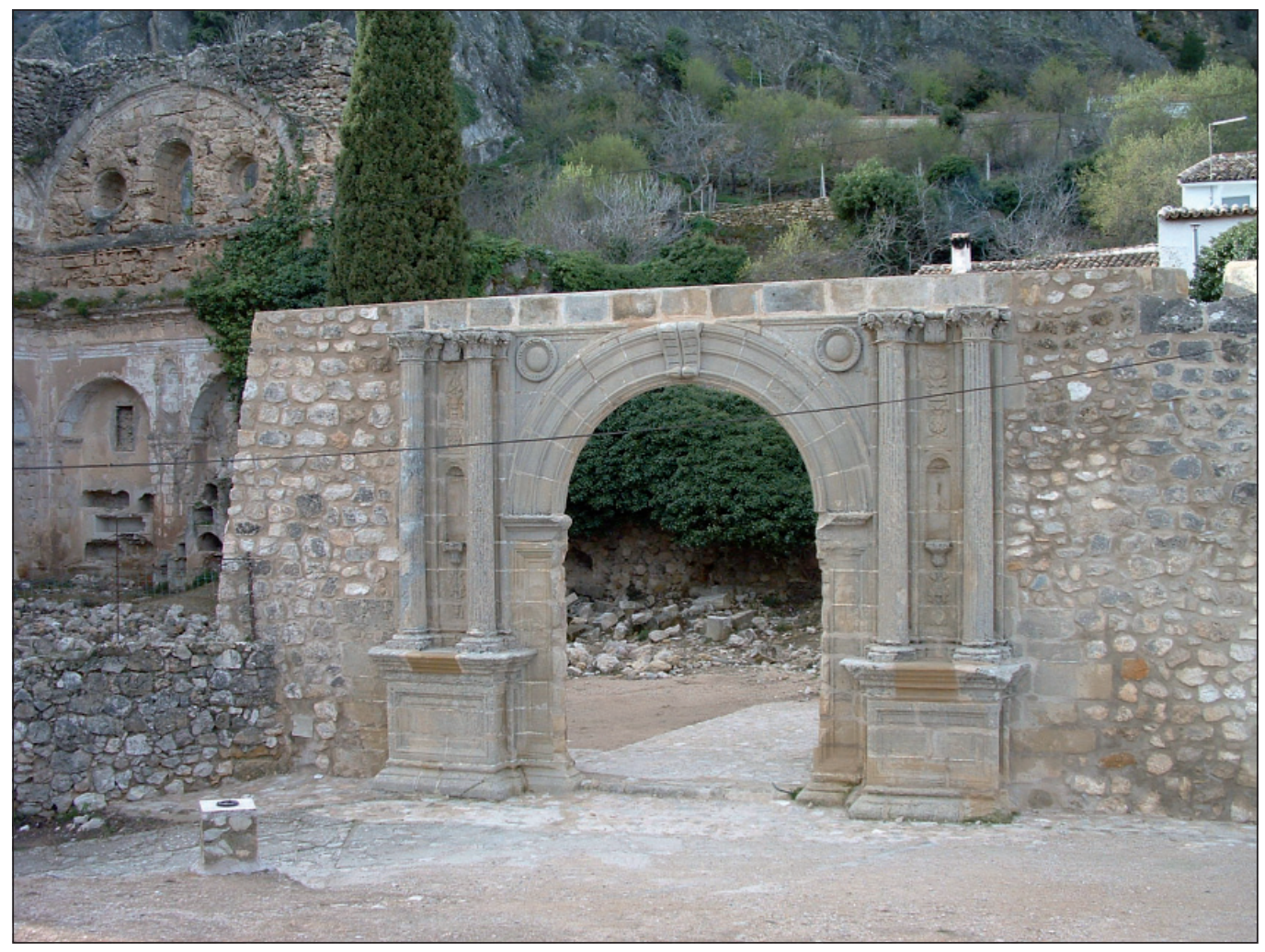

Fig. 15. Portada principal norte reinstalada 


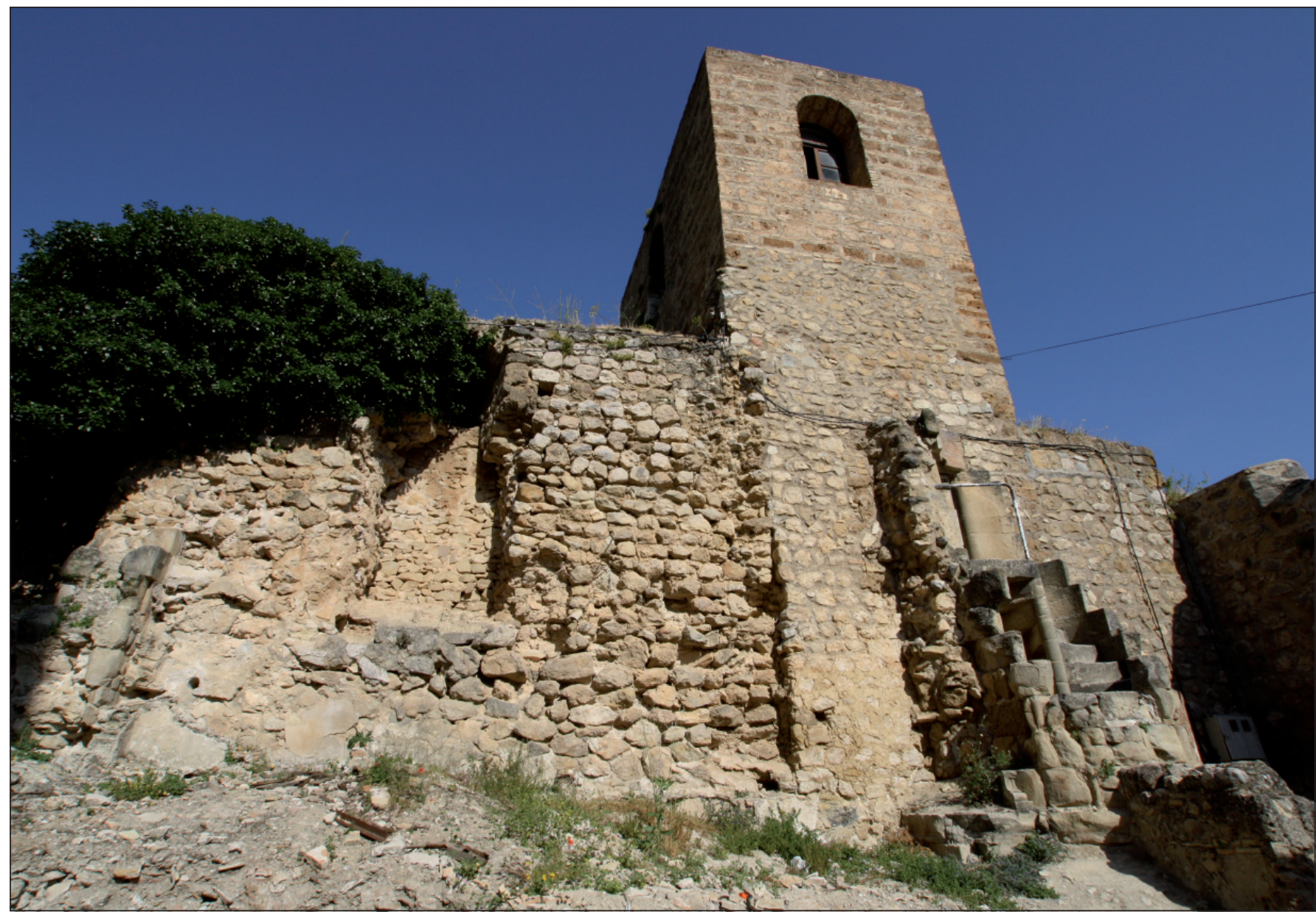

Fig. 16. Muro oeste interior. De derecha a izquierda se observan la escalera, la ventana y la pilastra en la que entregaba la arcada de la nave sur

comprobar que esta última apoyaba prácticamente sobre la roca sin casi cimentación, mientras que la norte, que probablemente era la principal, se reinstaló a finales del siglo XX mediante un muro moderno por lo que no es posible asegurar que ese fuera exactamente su sitio (fig. 15). El paramento que cierra el edificio por el oeste (fig. 16), presenta al norte una escalera de caracol, que da acceso a la segunda planta de la torre-puerta de entrada a la plaza y que fue empleada como campanario. Hacia el centro-sur del mismo paramento quedan huellas de una gran ventana cuyas jambas eran sillares de gran tamaño, con derrame hacia el interior. Al oeste de la misma se conservan restos de la pilastra donde se entregaban los arcos que separaban las naves central y sur, mientras que la correspondiente al lado norte ha desaparecido.

\section{LA SECUENCIA ARQUEOLÓGICA Y CONSTRUCTIVA}

El levantamiento planimétrico base de la fortaleza de La Iruela (castillo e iglesia) que utilizamos fue realizado por Estudio Arcadia S.C. y nos fue facilitado por el mismo para el estudio del castillo9. La fotogrametría base del edificio de la iglesia de Santo Domingo fue encargada por Pedro Salmerón, arquitecto responsable de la restauración de la iglesia, a la empresa Yamur S.L. y se nos entregó para la realización del estudio de los paramentos, habiéndose adaptado para esta finalidad. La lectura de estos paramentos, la excavación efectuada y el estudio de fuentes documentales nos han permitido reconocer un total de siete fases en la evolución del conjunto, las dos primeras anteriores a la construcción de la iglesia (fig. 17).

\section{Fase I. Siglos XII-XIII}

Corresponde a la ocupación de época almohade, la más antigua registrada. Probablemente se construyeron los tres recintos del castillo, mientras que el área de acceso al mismo, al oeste, parece que no fue ocupada, puesto que los

${ }^{9}$ Paralelamente al estudio de la iglesia de Santo Domingo, pero independientemente de aquel, la Excma. Diputación Provincial de Jaén nos encargó el análisis arqueológico del castillo, a propuesta del arquitecto Carlos Porras responsable de la restauración del mismo, y miembro de Estudio Arcadia S.C. 


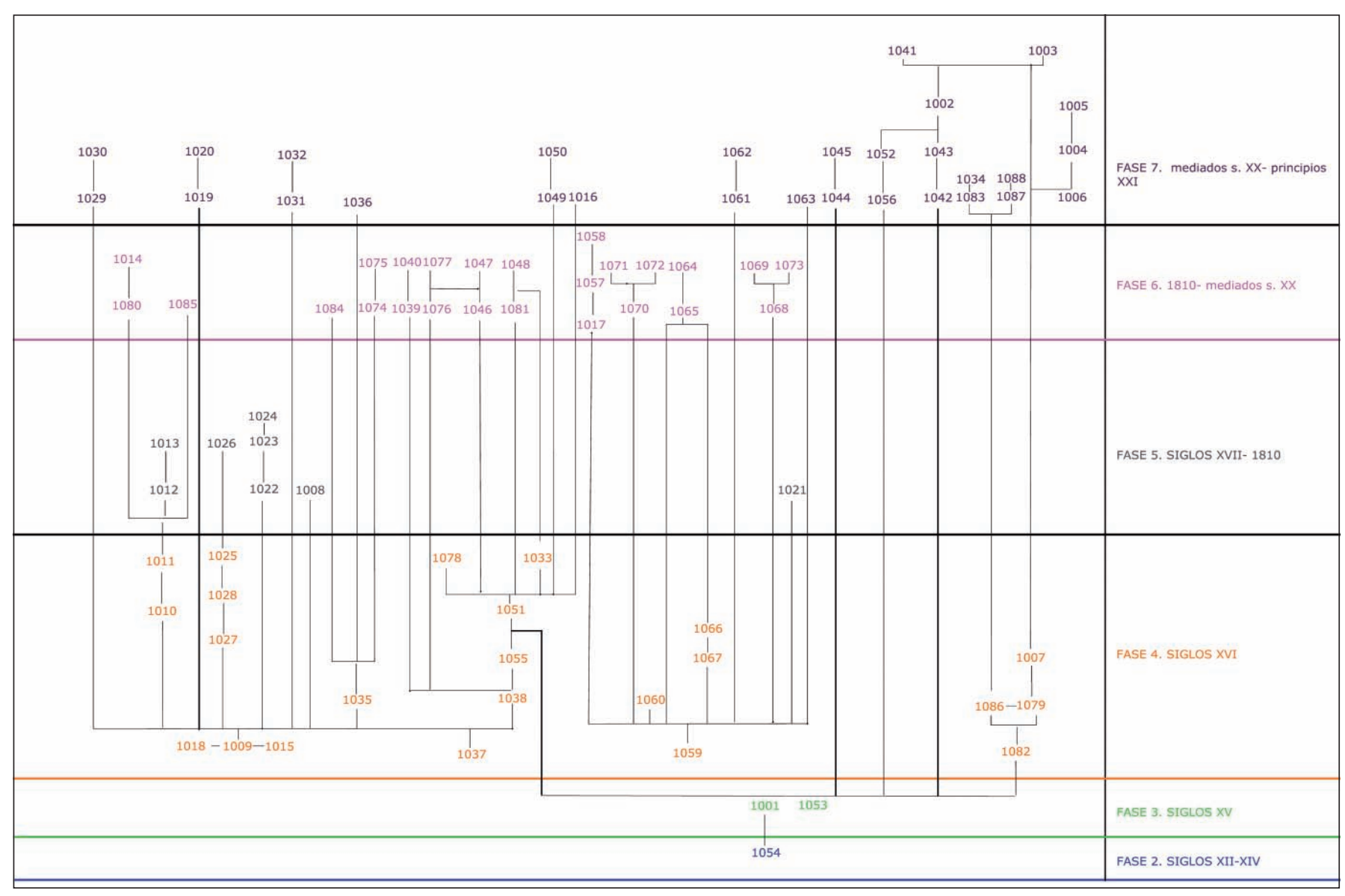

Fig. 17. Matrix de las estructuras elevadas

niveles más antiguos detectados corresponden ya a época bajomedieval. Al sur de este conjunto se ubicó la aldea islámica, en torno al área por donde discurría una vaguada. Entre ambos sectores existe un corte natural del terreno, que se acentúa de este a oeste debido a la pendiente de la mencionada vaguada. El área de la población sólo se ha excavado bajo la iglesia, situada al oeste, a la altura de la zona de acceso al castillo. En ella se ha comprobado que el desnivel natural se aprovechó para cortar la roca, muy blanda, a unos $20 \mathrm{~m}$ de la cabecera de la iglesia actual, de forma que se formaron dos terrazas oeste-este con un desnivel de casi 3,00 metros entre ellas; en la inferior, sobre la roca, se han localizado varios niveles con material de época almohade que no han podido relacionarse con ninguna estructura construida (Navarro, Gutiérrez en prensa; Salvatierra en prensa). Ningún elemento de esta fase puede vincularse con los paramentos de la iglesia.

\section{Fase II. Siglos XIII-XIV. La primera iglesia y el cuarto recinto}

Tras la conquista castellana en 1233, o quizá después de la obtención del privilegio de villazgo en 1378 , se llevaron a cabo diversas intervenciones en la zona donde luego se levantará la iglesia de Santo Domingo. En primer lugar, en la terraza inferior mencionada, y sobre los niveles almohades, se construyó —o transformó- un edificio de mampostería encofrada, que en el estado actual de las investigaciones cabe pensar que fuera la primera iglesia de la localidad, sin descartar totalmente que se trate de una mezquita transformada. Ninguna parte de este edificio fue empleado en la iglesia posterior. En segundo lugar se construiría una muralla englobando el área de acceso al castillo y la aldea. A la misma podrían pertenecer restos de un lienzo de tapial de gran dureza, aunque relativamente delgado, situado sobre el cortado, al norte del área de acceso al castillo ${ }^{10}$. Y con más seguridad los restos de un muro, constituido por mampuestos de mediano tamaño unidos con mortero (UE 1054) que quedaron integrados en el paramento oeste de la torre-puerta; y la torre hoy integrada en la llamada Casa de la Orden, al exterior de la torre-puerta y frente a los pies de la iglesia. Por otro lado, es probable que se limitase el paso entre el castillo y la aldea

\footnotetext{
${ }^{10}$ En este caso habría existido una primera muralla, quizá almohade.
} 
mediante otro lienzo que iría desde la torre sur del castillo hasta enlazar con la nueva muralla, de forma que se crearía una plaza de armas. No obstante, hay que advertir que la construcción de la iglesia renacentista, y posteriormente la reorganización del espacio situado en su frente norte, con el rebaje del desnivel existente respecto a la plaza, y la apertura del camino actual, ha eliminado cualquier resto consistente de dicho lienzo, por lo que la hipótesis se apoya en la posterior construcción de la torre-puerta.

\section{Fase III. Siglo xv. Construcción de la torre-puerta}

En el siglo XV la puerta del hipotético muro que separaba la población de la plaza de armas, se sustituyó por una torre-puerta, que sigue siendo hoy el acceso a la plaza y al castillo (fig. 18). La única parte original que queda de la misma corresponde al primer cuerpo, realizado con mampostería irregular unida con mortero (UE 1001). De planta rectangular, tiene unas dimensiones de $6,00 \times 4,00$ $\mathrm{m}$ en su base, que es ligeramente más ancha que el resto del cuerpo, lo que le daría mayor solidez, algo necesario por la existencia del amplio vano que ocupa la mayor parte de la misma, y que ha sufrido una serie de reparaciones en

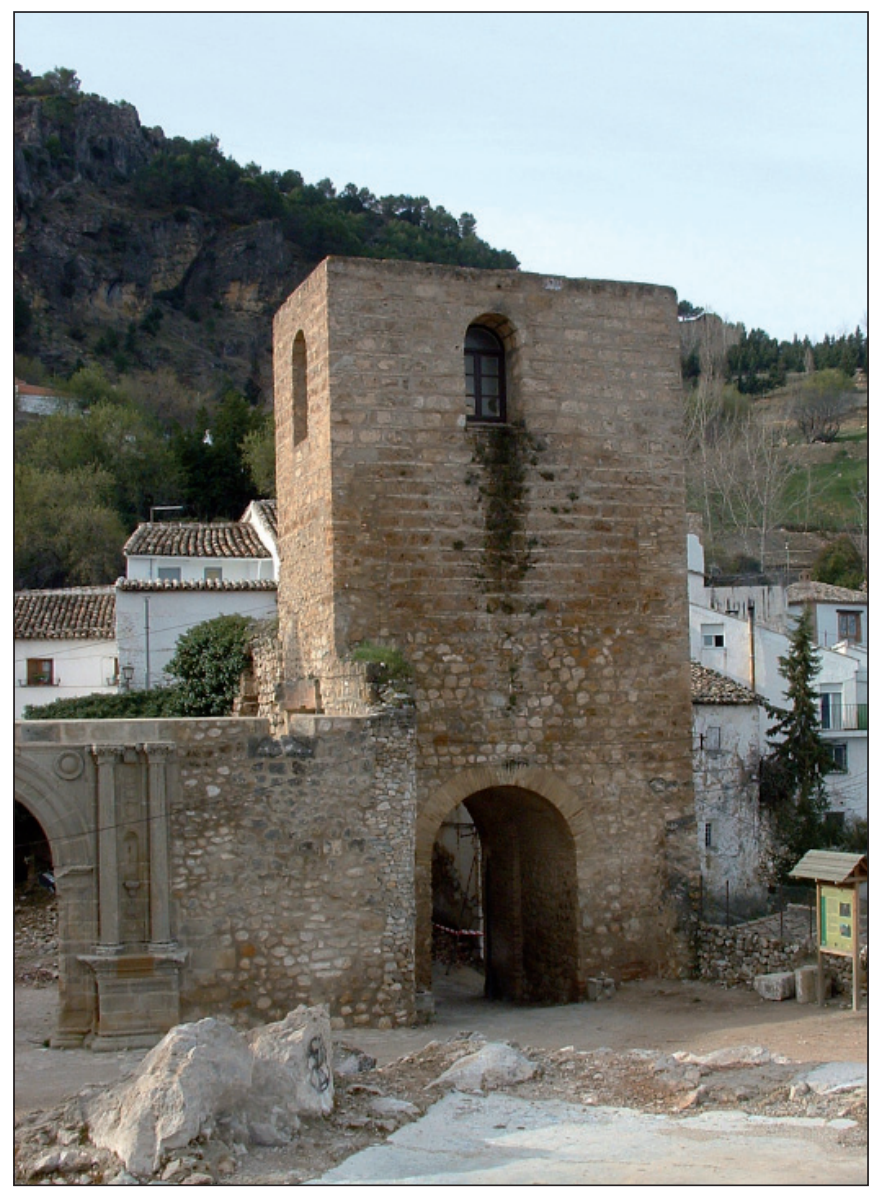

Fig. 18. Torre-puerta desde la plaza tiempos recientes. El lado oeste se adosa al muro de mampostería (UE 1054) al que ya nos hemos referido, la interfacie (UE 1053) que presenta sugiere que se eliminó el muro de cierre transversal también citado. Los cuerpos superiores están muy restaurados.

\section{Fase IV. Siglo xvı. Construcción de la iglesia}

Como se ha expuesto en la descripción, los muros y cimentaciones presentan una profunda diferencia entre las zonas este y oeste, aunque aparentemente todos se realizaron mediante dos paramentos paralelos, con un relleno entre ambos de calicanto muy irregular, con piedras de pequeño tamaño trabadas con tierra y cal (UE 1009). Al este, los gruesos muros de la cabecera apoyan en potentes cimientos. Por el exterior los paramentos presentan dos tipos de aparejo, separados por una cornisa (figs. 19 y 20). La parte inferior está realizada con sillares de color rojizo (UE 1018), piedra arenisca característica de la Loma de Úbeda, de donde sin duda procede. Presentan módulos de tamaño grande, y aunque con variaciones, la mayoría oscila entre los $0,84 \times 0,42 \mathrm{~m}$ y los $0,60 \times 0,44 \mathrm{~m}$. No obstante, por debajo del nivel de las capillas del lado norte, el muro presenta junto al primero otro tipo de sillar muy diferente por su tamaño y talla (UE 1011), existiendo una interfacie entre los dos tipos (UE 1010). Un sondeo arqueológico realizado al pie de los mismos demostró que ambos tipos apoyan en los mismos sillares de cimentación y comparten idéntico proceso de colmatación, lo que implica que corresponden al mismo momento constructivo. Por encima de la cornisa se emplea sillarejo de toba (UE 1015) igualmente de diversos tamaños con una media aproximada de $0,50 \times 0,33 \mathrm{~m}$.

Finalmente hay que señalar que en la zona norte del paramento exterior de la cabecera una interfacie (UE 1027) demuestra que se añadió un conjunto de gran complejidad, que incluye un gran arco de medio punto que cubre el supuesto vano de acceso exterior a la cripta, coronado a su vez por lo que parece una ladronera, realizada con sillares regulares de mediano tamaño bien trabajados (UE 1028), muy diferentes a los empleados en los paramentos, en la que se conserva la delimitación del espacio (UE 1025) donde debía haber encastrado un escudo, por lo que quizá el conjunto tuviera una función simbólica. Por el tipo de material empleado, cabe interpretar la inferfacie como una fase de obra, con poca diferencia cronológica respecto al resto.

Por el interior del templo probablemente se empleó también sillar en toda la parte inferior, aunque el paramento del presbiterio se encuentra enlucido (UE 1066) y muy 


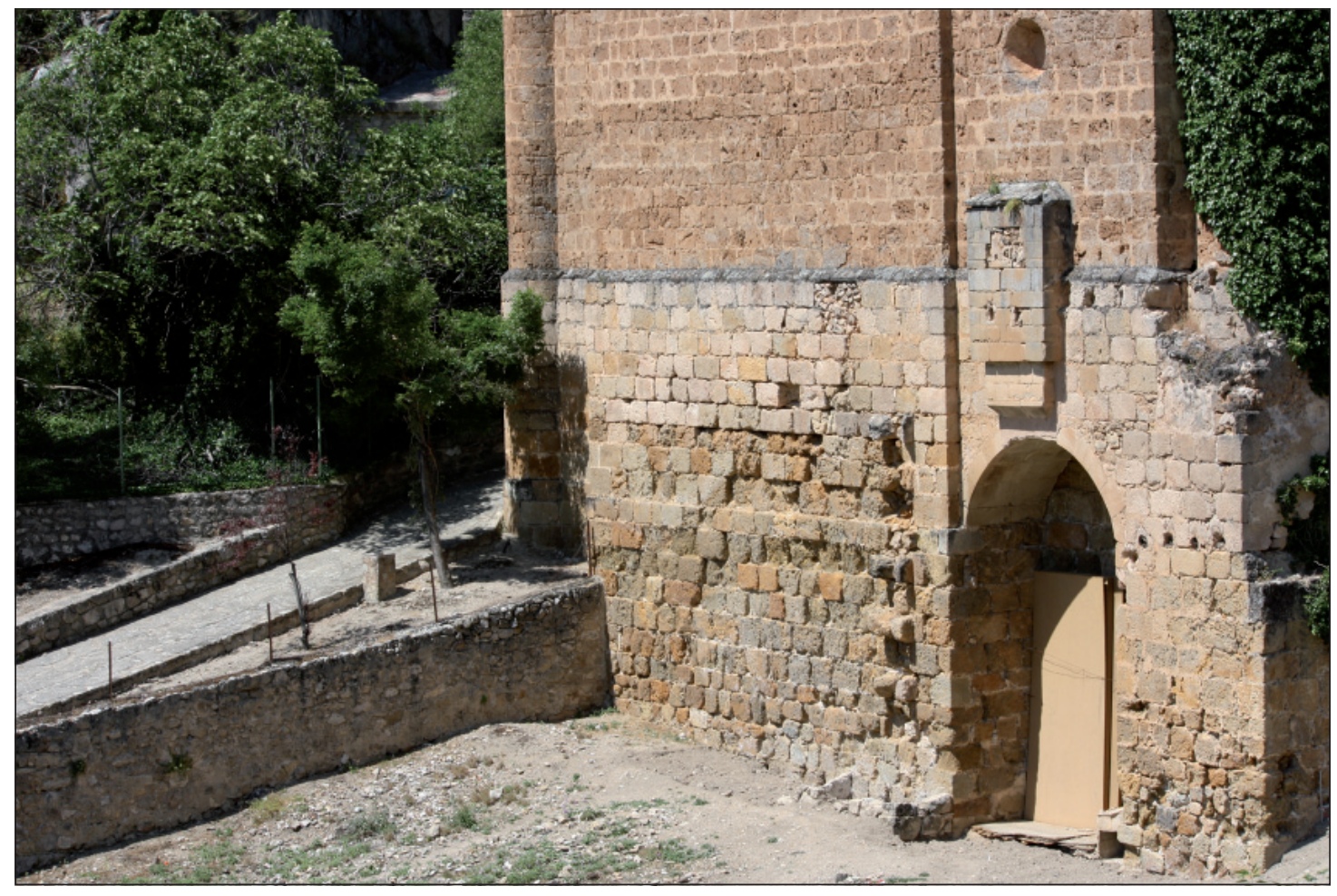

Fig. 19 Paramento este exterior de la iglesia

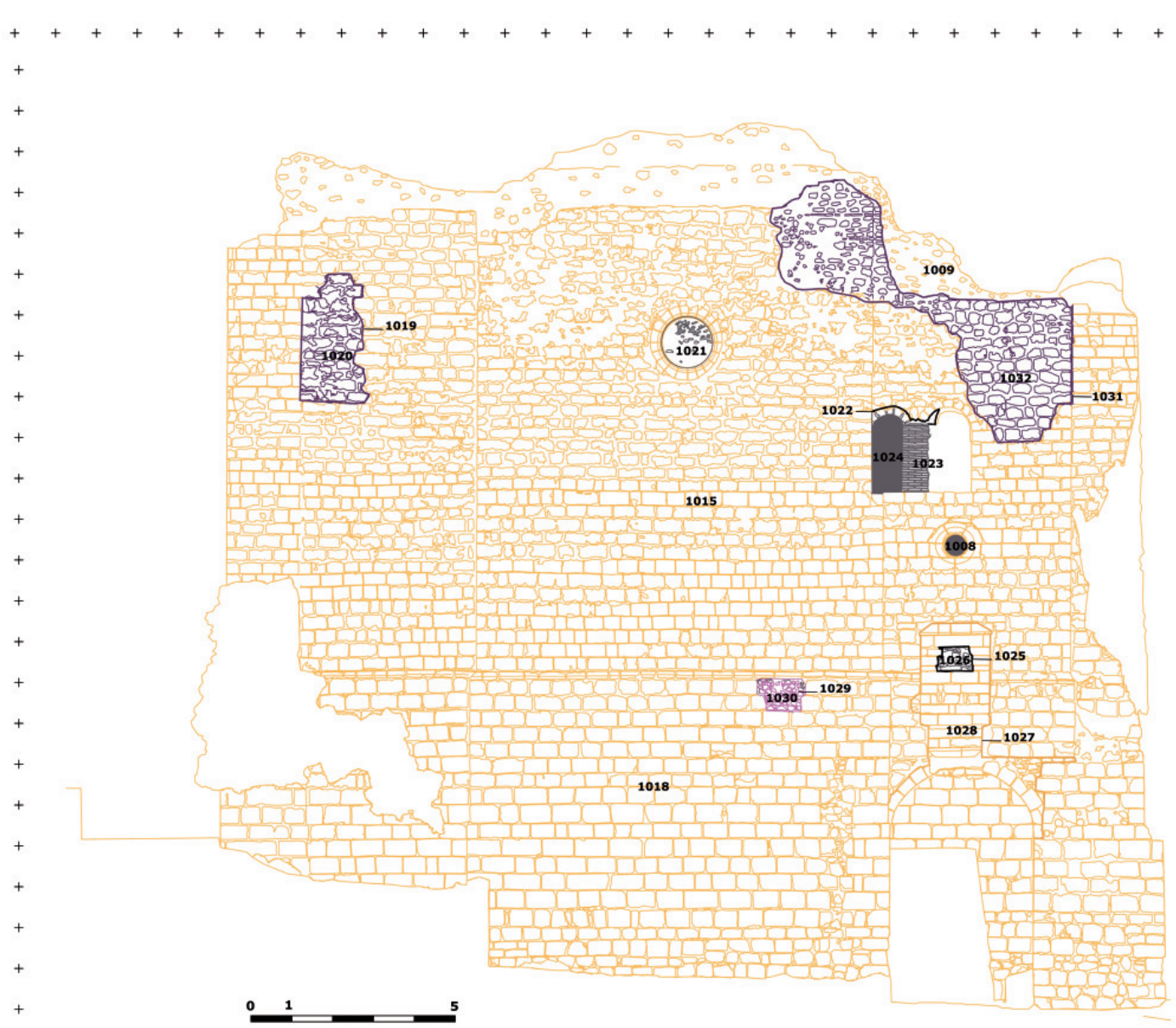

Fig. 20 Lectura del paramento este exterior. (Fotogrametría base Yamur S.L. Elaboración propia) 


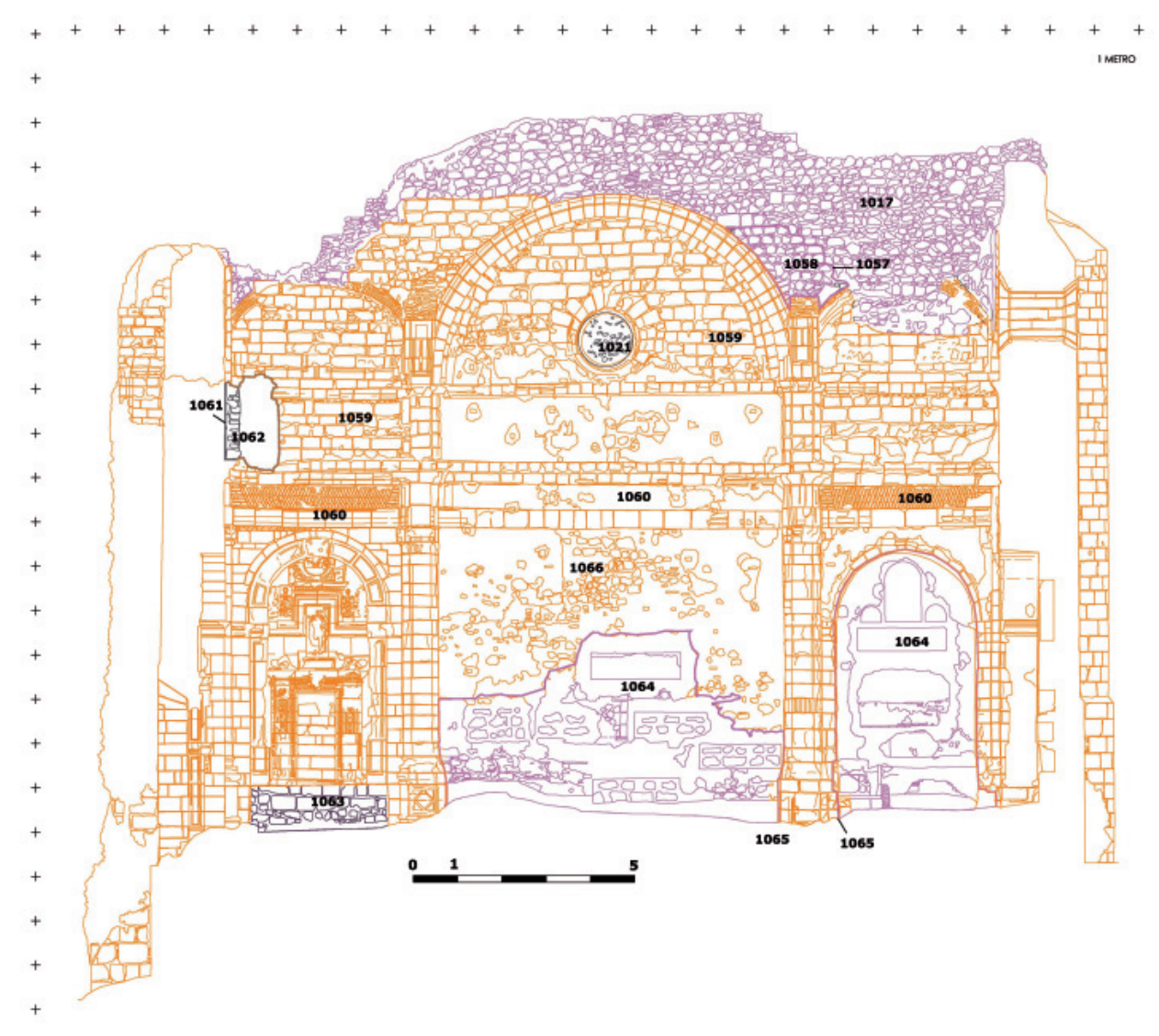

Fig. 21 Lectura del paramento de la cabecera, este interior. (Fotogrametría base Yamur S.L. Elaboración propia)

afectado por la apertura de nichos de enterramiento (fig. 21). En la parte superior del muro se repite el uso de sillarejo, menos en la zona correspondiente al presbiterio y en el arco que lo cubre, donde se empleó el sillar. En el coronamiento sólo se conserva sillarejo de toba en la pechina norte (UE 1060) y en el crucero sur. Por debajo de la cornisa se creó un espacio a modo de friso (UE 1059) para insertar la decoración, que en la actualidad ha desaparecido casi por completo.

El muro perimetral de la mitad suroeste de la iglesia y el cierre de los pies fueron realizados con mampostería, aunque el paramento exterior presenta una estructura muy poco homogénea debido a numerosas alteraciones. La portada sur (UE 1037) de la iglesia está formada por grandes sillares rojizos, muy trabajados y pulidos (fig. 22), entre esta y el crucero hay mampostería irregular (UE 1035) probablemente resultado de reparaciones, mientras que en el tramo al oeste de la puerta subsistirían los elementos originales (UE 1038), compuestos por un paramento de mampostería con un encintado con mortero, rematado en la esquina por grandes sillares encadenados, aunque toscos (fig. 23), que se prolongan a modo de base del muro oeste hacia el norte, marcándose claramente el límite del mismo (UE 1055). El resto del muro oeste, que se adosaba a los lados de la torre, era de mampostería irregular ordenada, tanto en el lado norte (UE 1007), como en el sur (UE 1051).

En este muro oeste, por el interior del templo, del momento de la construcción (figs. 16 y 24) se conserva el arranque de la pilastra (UE 1078) donde se entregaban los arcos que separan la nave central de la sur. Hacia el centro, en la parte superior, había una gran ventana con jambas de derrame, constituidas por grandes sillares muy cuidados de los que quedan algunos (UE 1033). Mientras que frente a la nave norte se encuentra la torre-puerta (UE 1001), en cuyo paramento se realizaron algunas reformas con el fin de utilizarla como campanario. Es posible que se eliminase una escalera original, y se sustituyese por la que hoy existe (UE 1079), apreciándose en la parte inferior el corte para introducirla (UE 1082). No obstante en la actualidad han desaparecido la mayor parte de los sillares que debían revestir los laterales, quedando al descubierto el relleno de mampostería irregular de grandes piedras que se aprecian a ambos lados de la escalera (UE 1086). 

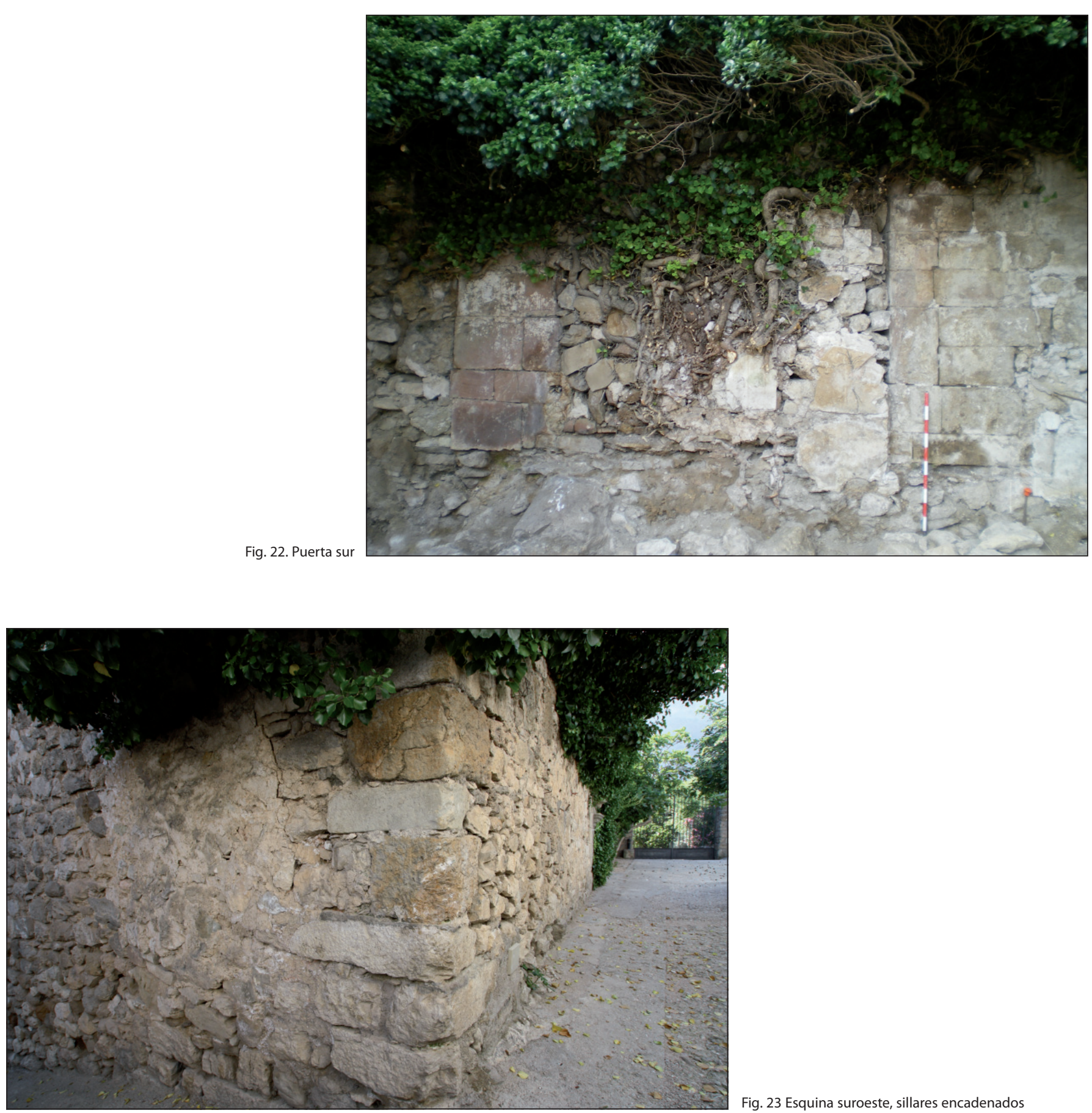

Fig. 23 Esquina suroeste, sillares encadenados

\section{Fase V. Siglo XVII - 1808. Reformas en la iglesia}

Entre los siglos XVII y XVIII, las actas capitulares conservadas en el archivo de La Iruela, recogen la existencia de constantes problemas de mantenimiento y la falta de recursos para atenderlos adecuadamente. Entre las reparaciones que es posible fechar en esta época por los materiales utilizados, podemos señalar el cierre de vanos como solución más barata para limitar posibles daños. Se tapiaron con mampostería de pequeño tamaño los rosetones
(UUEE 1008, 1021) quizá por no disponer del cristal emplomado que debería cerrarlos y dejar pasar la luz. En la hipotética ladronera se rellenó con mampostería (UE 1026) el hueco del que quizá se había extraído un escudo. También la ventana de la habitación existente en la cabecera se convirtió en una ventana geminada mediante un pilar de ladrillo (UUEE 1022, 1023), y posteriormente se cegó uno de los nuevos vanos (UE 1024) con mampostería recubierta de argamasa. En el lado noreste, en la 


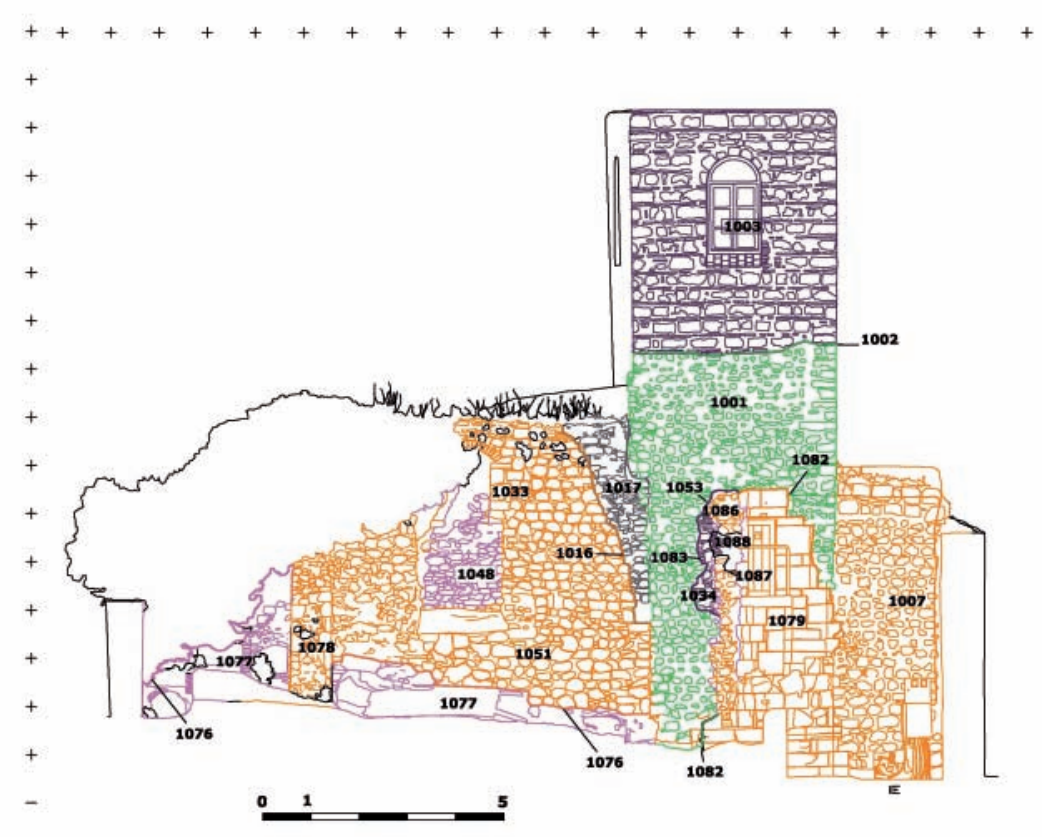

Fig. 24 Lectura del paramento oeste interior. (Fotogrametría base Yamur S.L. Elaboración propia)

capilla izquierda, se eliminó gran parte del cierre de la misma para abrir un vano, ello provocó la eliminación o caída de materiales del paramento exterior (UE 1012), que fue repuesto con mampostería de pequeño tamaño (UE 1013). La situación de deterioro es explícita en 1751, momento en el que el Catastro de Ensenada, señala:

\section{"lo que causa mayor dolor es ver la fabrica de la parroquial mayor de Santo Domingo de Silos por acabar, siendo esta bastamente decente, y por los muchos hostigos y tejados con los que hoy se halla, por no estar perfeccionada padece el continuo detrimento de tan continuos gastos para poder conservarse sin que se arruine pudiendo subbenir la cortedad de sus rentas attan patente necesidad $\aleph^{11}$.}

Ello quizá implique que la iglesia no terminó de cubrirse adecuadamente, y se emplearon fórmulas de emergencia que no dieron resultado. Pero naturalmente no ha sido posible aclarar dicho aspecto.

\section{Fase VI. 1808- 1953. Cierre de la iglesia y apertura del cementerio municipal}

Según las actas capitulares, la población sería atacada en diversas ocasiones por las tropas napoleónicas durante la guerra, y, al parecer, la iglesia sufrió importantes daños y fue incendiada ${ }^{12}$. En ocasiones se ha indicado que el enrojecimiento de los sillares de determinados materiales

\footnotetext{
${ }^{11}$ AHPJ. Catastro del Marqués de la Ensenada. Relaciones de bienes eclesiásticos, 1751, libro núm. 7766.

${ }^{12}$ A.M.C. Actas Capitulares
}

puede ser efecto de fuegos intensos durante cierto tiempo, por descomposición química. En el caso de La Iruela la coloración natural de buena parte los propios sillares y sillarejos dificulta tener en cuenta este aspecto. No obstante ese fenómeno sí puede considerarse que se produce en la jamba oeste de la puerta sur (fig. 22) y con más dudas en el extremo noreste (fig. 14), aunque no es suficiente para afirmar que efectivamente hubo un incendio generalizado.

Bien como consecuencia de esas actuaciones, o por el estado de deterioro del edificio, éste se arruinaría definitivamente por esta época. Sería entonces cuando caería la techumbre, aunque quedó en su sitio la pechina realizada en sillarejo de toba, la caída arrastró buena parte del sillarejo de la parte superior del paramento este (UE 1057), hasta la parte superior del gran arco del presbiterio, incluyendo la pechina del lado sur, dejando al descubierto el relleno de calicanto interior. Para impedir la caída de éste y detener el deterioro del muro de la cabecera se reconstruyó la pechina con sillarejo regular de color gris claro (UE 1058) y parte del anterior paramento con mampostería irregular ordenada (UE 1017). También sería entonces cuando desapareció gran parte del paramento norte, desde la esquina suroeste hasta casi la pilastra y el contrafuerte que separaban la nave del crucero, advirtiéndose claramente cuál es el límite del muro original (UE 1085). En éste (fig. 25) se observan nuevas intervenciones en la capilla oeste, apreciándose una nueva ruptura, que incluso afectó a los sillares de la parte inferior (UE 1080), reponiéndose 


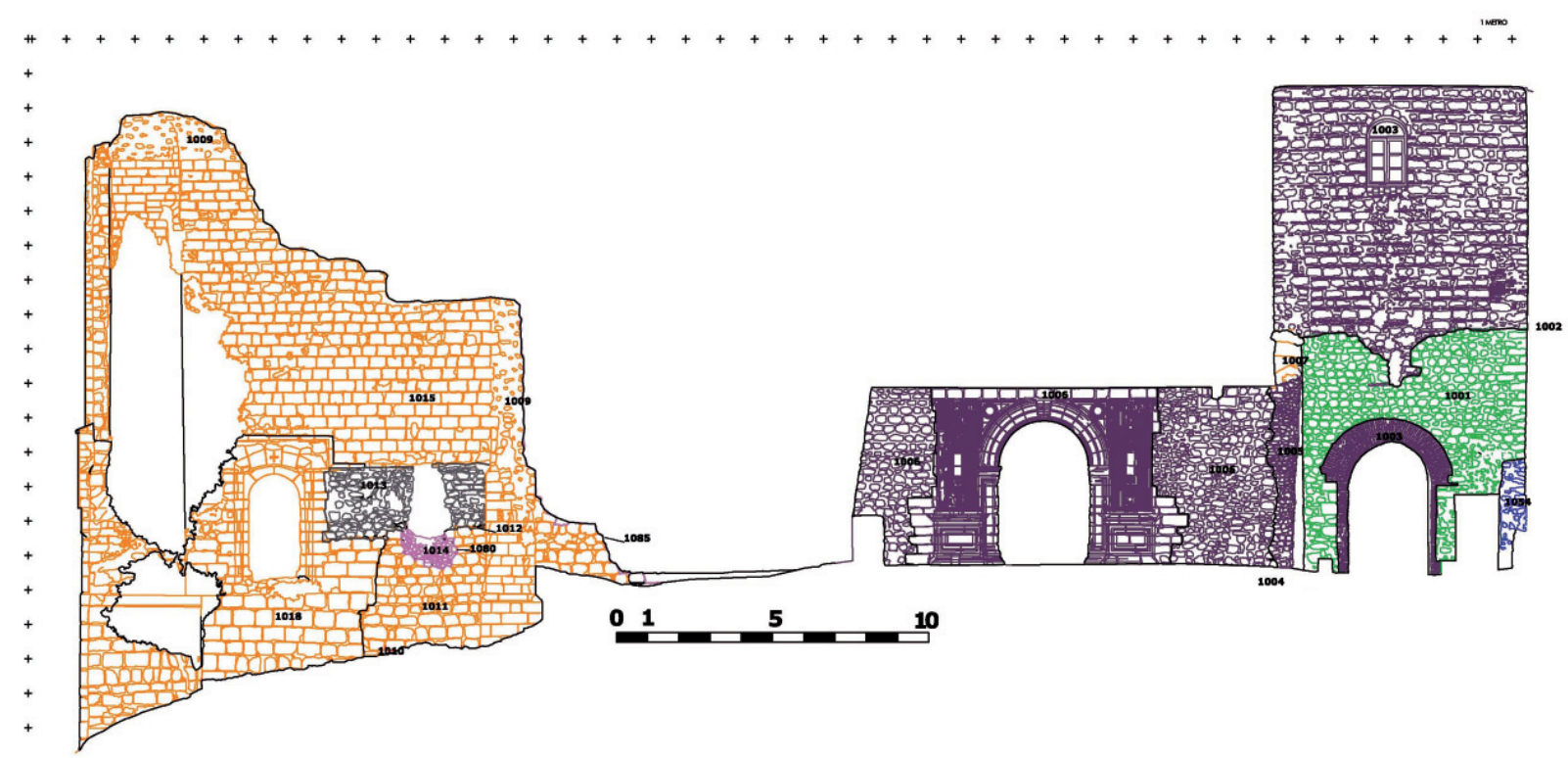

Fig. 25 Lectura del paramento norte exterior. (Fotogrametría base Yamur S.L. Elaboración propia)

la rotura de estos con mampostería de mediano tamaño sin argamasa (UE 1014) ${ }^{13}$.

Todas estas destrucciones debieron producir la supresión del culto en la iglesia y el abandono de la misma, ya que Pascual Madoz en 1854 sólo menciona la iglesia de Nuestra Sra. de la Concepción (Madoz 1988:98). A partir de ese momento se intensificarían los problemas en el interior del edificio, sobre todo los provocados por el agua, que penetraba por los poros de la piedra y al congelarse producía la descamación de la misma y, en ocasiones, la ruptura de trozos mayores. De igual modo, se produjo la lenta destrucción de casi todos los frisos decorativos.

Aunque probablemente nunca dejó de enterrarse en la iglesia, sería ahora cuando se convertiría en cementerio municipal. En los muros de la mitad sur (cabecera, lateral y pies) se delimitarán áreas (UUEE 1068, 1070, 1074, 1076) para la apertura de nichos en los que se abrirán numerosos de éstos (UUEE 1064, 1065, 1069, 1071, 1075, 1077), así como huecos para la colocación de grandes lápidas (UUEE 1072, 1073), e incluso para alguna escultura funeraria (UE 1084). En la cabecera los nichos son paralelos al muro, lo que unido al notable grosor de éste, su construcción no afectó a la parte exterior del mismo. Pero en los otros dos lados son perpendiculares a los muros, por lo que algunos los atravesaron y produjeron daños en el paramento exterior, lo que explica las rupturas

\footnotetext{
${ }^{13}$ Estos materiales fueron eliminados siguiendo las instrucciones del arquitecto, al consolidar el muro durante la intervención arqueológica efectuada en 2009, ante el peligro de derrumbe de todo el paramento.
}

y reparaciones existentes en los muros sur (UUEE 1039, 1040) y oeste (UE 1046), realizadas con mampostería irregular de pequeño tamaño unida con mortero o cemento, y en ocasiones recubierta por mortero (UE 1047). El tipo de adhesivo empleado debe relacionarse con el momento concreto en que se llevaron a cabo las reparaciones. Finalmente, en la ventana del muro oeste se advierte que se extrajeron la mayor parte de los sillares que la enmarcaban, con lo que se rompió exteriormente algo más (UE 1081) tapiándose después con argamasa o cemento (UE 1048). Quizá se trataba de darle mayor solidez al muro ante la apertura de los nichos aunque según noticias orales, en dicha zona el espacio se empleó para algunas actividades forenses previas a la inhumación, por lo que el cierre del vano pudo estar en función de evitar las miradas desde el exterior. Por otro lado, también se enterró en el suelo en todo el ámbito de la iglesia y en la zona situada al este, al exterior de la misma. Quizá para acceder a este último sector se eliminó, o no se repuso, parte del muro norte, ya que es la única zona que no aparece reparada. El cementerio aún funcionaba en los años sesenta del siglo XX, incluso después de que se construyera uno nuevo algo más lejos de la población. Finalmente, al clausurarse, se extrajeron los enterramientos de los nichos, pero dejando un buen número de los enterrados en el suelo.

\section{Fase VII. Mediados del siglo xx - principios del XXI}

El abandono del cementerio debió ir seguido de la desaparición de la puerta del mismo, convirtiéndose este espacio 
en un lugar semipúblico en el que se llegaron a ocasionar algunos desperfectos como la rotura lateral del panteón del siglo XVIII (UE 105) y, sobre todo, la del extremo de la bóveda de la cripta (UE 119), por la que con el tiempo irían cayendo o arrojándose gran cantidad de escombros procedentes del derrumbe o reparaciones de la parte superior de la cabecera de la iglesia.

En el último tercio del siglo XX se inició un lento proceso de recuperación y puesta en valor del conjunto. Sin duda, la principal intervención fue la reposición de la mitad oeste del paramento norte con la antigua puerta (UUEE 1004, 1006) y, en la esquina noroeste, en vez de los sillares encadenados que aparecen en el ángulo suroeste, se colocó mampostería regular unida con cemento (UE 1005). Pero no se levantó completamente el muro norte, dejándose un amplio espacio vacío entre el mismo y el correspondiente al crucero, de forma que pudiera accederse a la parte posterior de la iglesia.

Al exterior de la cabecera, en la zona superior del muro, parte del sillarejo del coronamiento se había desprendido, dejando al descubierto el calicanto interior, por lo que se realizaron algunas reparaciones consolidando la parte superior del muro; al sur en una amplia zona dañada (UE 1019) se empleó un característico llagueado de color blanco (UE 1020), mientras que al norte aparece una amplia zona (UE 1031) arreglada con mampostería irregular desordenada (UE 1032). Así mismo, en los sillares del paramento exterior se observan diversos desperfectos (UE 1029), que fueron reparados con mampostería irregular de pequeño tamaño (UE 1030). Por el interior se redujo el tamaño del vano de acceso a la habitación superior del lado noreste de la cabecera (UE 1061) añadiendo una jamba de piedras y cemento (UE 1062), posiblemente por problemas en el dintel de la misma, cuyo derrumbe habría debilitado o incluso provocado la caída de parte del muro. Así mismo se cerró con un nuevo paramento (UE 1063) la parte inferior de la capilla del lado norte.

En el muro oeste se advierte un corte en el paramento (UE 1016) en las inmediaciones del ángulo de la torre, consecuencia de la caída de la mampostería, que dejó al descubierto el relleno original interior. En relación con la escalera, la desaparición de los sillares del lado sur que dejó al descubierto el relleno, produjo una nueva ruptura (UE 1083) en la torre, que se rellenó con ladrillos y piedras (UE 1034). Por último y se cortó (UE 1087) el muro lateral sur (UE 1086), rellenándose con cemento y piedras (UE 1088) con el fin de sujetar el extremo de una barandilla de metal que se introduce en estos momentos.
Finalmente, tuvieron especial importancia las actuaciones en la torre-puerta. En ella se reconstruyó la parte superior (UE 1002, 1003), empleando mampostería irregular alternando con verdugadas de ladrillo. En la primera planta se abrieron o modificaron ventanas en cada una de las caras (UUEE 1044, 1045, 1052, 1056) y se llevaron a cabo arreglos puntuales. En la planta baja, en el acceso, se reconstruyó el arco de ladrillo y las jambas (UE 1043). Al mismo tiempo se realizó un socalce en la esquina sur (UE 1041), donde la argamasa recubre los mampuestos. Al oeste, relacionada con la escalera de subida a la torre, se llevó a cabo una modificación en la misma se rompió el paramento de la torre (UE 1087) introduciendo un muro (UE 1086) que se adosó en un par de puntos para proteger mejor la subida, y en los que se encastró una barandilla. Además se arregló la jamba de la puerta de acceso a la torre (UE 1042). Otras reparaciones se efectuaron en el muro oeste, más evidentes en su contacto con la torre; en casi todas ellas se empleó mampostería o ladrillo, trabados con cemento. Al exterior del mismo, junto a la torre, se instaló el sistema eléctrico para la iluminación del conjunto (UE 1050), que supuso nuevas rupturas (UE 1049) de este paramento.

A principios del nuevo milenio se ha iniciado la recuperación del edificio realizándose excavaciones arqueológicas para documentar diversos aspectos, y una primera consolidación de lo que aún subsiste.

\section{EL PROBLEMA DE LA AUTORÍA}

En diversos puntos del trabajo se ha hecho alusión a la cuestión no resuelta de la autoría del edificio, tema que para esta época resulta fundamental para establecer las conexiones estilísticas, influencias, etc. A continuación vamos a tratar de sintetizar los parámetros del problema. Hay que tener en cuenta que terminada la conquista del reino nazarí de Granada en 1492, se desarrollará una febril actividad constructora en Andalucía oriental, tanto por parte de la iglesia como de la alta nobleza, que no sólo impulsará la construcción de sus palacios, sino que muchos de sus miembros van a llevar a cabo un importante mecenazgo sobre obras religiosas, en una clara imitación de la actuación de los monarcas. No obstante, la construcción de las iglesias parroquiales será competencia de los respectivos obispados, y en el caso de las localidades del Adelantamiento de Cazorla esta correspondía al arzobispado de Toledo. En La Iruela se construyeron dos iglesias, la de Santo Domingo y la de La Concepción, y es posible que ambas obras se realizasen sucesivamente para cubrir el crecimiento de la población que se produjo a lo largo del 
siglo XVI, y que por tanto fueran impulsadas por sucesivos arzobispos.

Pero la entrega del señorío en 1534 a Don Francisco de los Cobos introduce una profunda incertidumbre, que se refleja en las opiniones de los distintos autores que hemos examinado, acerca de la intervención de Andrés de Vandelvira, «su» arquitecto en la zona. Tenemos bastantes datos sobre la actividad constructora del secretario de Carlos $\mathrm{V}$ y de sus herederos, los marqueses de Camarasa, actividad que en el Adelantamiento estaría motivada en parte para justificar su posesión del mismo, y cuyo «buque insignia» sería la construcción de la iglesia de Santa María, en Cazorla.

Como se ha señalado anteriormente, se ha sugerido el inicio de la construcción de la iglesia de Santo Domingo de La Iruela hacia el segundo tercio del siglo XVI, en consecuencia, la misma pudo ser promovida tanto por el arzobispado, sobre todo si se inició antes de 1534 (Galera 2000b:300), como por el poderoso secretario de Carlos V si fue después de esa fecha, o por sus herederos, tras la muerte de aquel en 1547.

Ante la falta de datos seguros sólo puede plantearse una hipótesis de conjunto. Parece muy probable que la construcción de la iglesia de La Concepción fuera financiada por el arzobispado, ya que se levantó en el eje de ampliación de la localidad. El diseño de esta ampliación debe ser de principios del XVI, y prevería dicha iglesia, que estaría destinada a presidir la nueva plaza de la localidad, aunque luego su posición prominente fuera disminuida por la construcción del edificio del pósito, que prolongó el final del ensanche. Esta última obra pudo ser impulsada por los herederos de Francisco de los Cobos, ante el enfrentamiento que en esos momentos ya mantenían con los sucesores del cardenal Tavera, para cimentar su prestigio en la zona.

En la misma línea, frente a la actividad del propio Tavera o de su sucesor el arzobispo Don Juan Martínez Siliceo (1545-1557), el secretario de Carlos V o sus herederos pudieron querer mostrar su fe impulsando la construcción de la iglesia de Santo Domingo dentro del ámbito de la fortaleza, sustituyendo al viejo edificio medieval. Esto explicaría que el tamaño de dicha iglesia sea relativamente notable en relación a la localidad en la que se inscribe. Esta iglesia empezaría a realizarse con la misma cantería que los principales contratistas empleaban en otras grandes obras de la Loma de Úbeda, pero el fallecimiento del secretario de Carlos V antes de la finalización de la misma, pudo obligar a sus herederos, que nunca dispusieron de sus grandes recursos económicos, a terminarla de modo mucho más rústico.
En cualquier caso, la falta de documentación de archivo sobre esta iglesia impide conocer con seguridad quién la levantó.

La misma falta de documentación que oculta al promotor del edificio, impide saber quién realizó las trazas del mismo y quiénes lo ejecutaron. Se han mencionado reiteradamente dos nombres: Andrés de Vandelvira y Rodrigo de Gibaja, aunque la mayoría de los autores lo hacen siempre con gran prudencia, apostando por que estos maestros pudieron dar las trazas o ejercer algún tipo de supervisión, que sería siempre muy relativa.

Andrés de Vandelvira, nacido en Alcaraz (Albacete), fue uno de los grandes maestros de la época, y especialmente vinculado a las obras del secretario de Carlos V, primero ejecutando las trazas de otros, como las de Diego de Siloé en la capilla de El Salvador de Úbeda, y luego realizando sus propios diseños (Galera 2000a). Pero dado su alto nivel técnico, comparado con el que refleja esta iglesia, quienes lo vinculan a Santo Domingo lo hacen con grandes precauciones, así Fernando Chueca (1971:305) consideraba que la iglesia, debió ser realizada por canteros locales, aunque tenía inspiraciones vandelvirescas; Pedro Galera recoge la apreciación de Fernando Chueca, aunque considera que la obra pudo iniciarse antes de 1534 y ser ejecutada por Rodrigo de Gibaja (Galera 2000b: 300), aunque admite que "cae dentro de la lógica que fuera proseguido por el maestro de Alcaraz...» (Galera 2007:2526), posición aparentemente opuesta a la de Miguel Ruiz Calvente quien señala «a Vandelvira se debe probablemente el plan general de la cercana iglesia de Santo Domingo de la villa de La Iruela, aunque su ejecución parece escapar de su control» (Ruiz Calvente 2007:202). Finalmente otros autores como Lázaro Gila y Vicente M. Ruiz (1992:100-101) aunque aluden a la posible relación de Vandelvira con ella, optan por no pronunciarse. Una de las razones para vincular a Vandelvira con esta obra es que al mismo se le atribuye la construcción del pósito de la población, aunque el mismo sería realizado después de 1572, es decir, ya por iniciativa de los condes de Camarasa (Galera 2000a:144-145; Galera 2000b; Galera 2007:25; Gila, Ruiz 1992:100-101; Montero et alii. 1991:237238;).

Por su parte, Rodrigo de Gibaja, maestro santanderino, llegó a Baza en 1538, para hacerse cargo de los trabajos en la capilla mayor de la colegiata de dicha población, trazada por Alonso de Covarrubias (Magaña 1954:38-40; Rubio 1990:137), lo que le vincula con la mitra toledana, lo que se refuerza al observar que buena parte de su obra se concentra en el noreste de la actual provincia de Granada, 
trabajando en numerosas obras del arzobispado de Toledo, aunque también trabajará activamente para la diócesis de Guadi $^{14}$. De hecho, con frecuencia ejecutará las trazas de los dos grandes maestros de la época, Alonso de Covarrubias, maestro mayor de la catedral de Toledo, y Diego de Siloé, arquitecto de la catedral de Granada, y principal tracista del obispado de Guadix. Así mismo influirá en su estilo Andrés de Vandelvira, hasta el punto de que en la actualidad, ante la falta de documentación, se duda sobre cual de los dos ejecutó la obra de la colegiata de Santa María de Huéscar, también sobre trazas de Siloé (Rubio 1990:137 y 141). Por lo que se refiere a la actuación de Rodrigo de Gibaja en La Iruela, la única información proviene de Luís Magaña, quién afirmó que trabajaba en 1538 en la iglesia de Santa María de Quesada y en la parroquial de La Iruela (Magaña 1954:39, nota 7; Rubio 1990:138). Aunque no aportó documentación, su afirmación no ha sido discutida, y se ha identificado esa iglesia con la de Santo Domingo (Galera 2000b:300; Moreno et alii 2005:488). Pero por su vinculación al arzobispado de Toledo, la iglesia en la que intervenía bien pudo ser de la de La Concepción. En este sentido, hace unos años el cronista Francisco Olivares (1987:277) señalaba efectivamente a este maestro como autor de esta última, aunque sin argumentarlo, ni lamentablemente aportar datos sobre sus fuentes.

No parece necesario aclarar que, aunque la iglesia de Santo Domingo fuese impulsada por Francisco de los Cobos o sus herederos, no tiene porqué resultar extraño que un arquitecto vinculado a la mitra toledana como Rodrigo de Gibaja trabajase en ella, ni a la inversa, que fuera promovida por el arzobispo, y colaborase Andrés de Vandelvira. Y ello porque no parece que las disputas entre señores afectasen a los maestros canteros, de lo que es un buen ejemplo la actividad de Rodrigo de Gibaja al servicio de las sedes de Toledo y Guadix. Obviamente, no se trata de la independencia de los "artistas»; hay que recordar que estos especialistas tenían la consideración de artesanos, y que eran los mecenas que encargaban las obras quienes establecían las condiciones y elementos que debían incluir en las mismas, con frecuencia con extraordinario detalle, ya que en las construcciones trataban de exponer auténticos programas políticos (Rubio 1990; Henares 1992).

\footnotetext{
${ }^{14}$ En la época se desarrollará un largo pleito entre el arzobispado de Toledo y el obispado de Guadix por el dominio del territorio nororiental de Granada, la antigua diócesis episcopal visigoda de Baza. Finalmente, en 1544 el territorio se repartió entre ambas diócesis, pasando Baza y otras localidades al obispado de Guadix, mientras que Galera, Huércar, etc. quedaban en el arzobispado de Toledo.
}

Además, ellos no contrataban a los maestros, sino que lo hacían sus administradores en la zona, y éstos lo que buscaban era la pericia para ejecutar los mandatos de sus señores, siendo probablemente irrelevante que dichos artesanos pudieran trabajar también para sus rivales. A pesar de todo, debemos reconocer que es extraño que el mismo arquitecto trabajase en las dos iglesias de La Iruela casi al mismo tiempo, sobre todo si las mismas se debían a dos promotores diferentes. Aunque la escasez de especialistas de primer nivel podría explicarlo, es obvio que sin más documentación no es posible salir del campo de las hipótesis. El "consenso» actual es que en apariencia, la obra sería ejecutada por canteros locales, a partir de trazas proporcionadas por alguno de los principales maestros que trabajaban en la zona.

\section{CONCLUSIONES}

En función de las fases establecidas con la lectura de paramentos y la excavación, podemos considerar tres grandes periodos en relación a la iglesia.

1. En cuanto al primer periodo, los escasos datos existentes, tanto escritos como arqueológicos, pese a sus limitaciones, apuntan a la existencia de una iglesia bajomedieval, que sería sustituida por la de Santo Domingo en el siglo XVI.

2. Respecto al segundo periodo, referido a la propia iglesia, la investigación debía aclarar, entre otras cuestiones, los problemas referidos a la cimentación, que resolvió adecuadamente la excavación, y establecer si la diferencia en los materiales empleados en distintas partes del edificio respondían a distintas fases constructivas o no. En este sentido, algunos de los cambios de aparejo, como la sustitución del sillar empleado en la parte inferior por el sillarejo en la parte alta, que se registra en la cabecera, cabe atribuirla al uso de materiales más ligeros en altura, un recurso bien conocido. En segundo lugar, la lectura de paramentos ha demostrado que el elemento aparentemente fortificado (UE 1028) que podía corresponder a un edificio anterior, es parte de la construcción original. En tercer lugar parece también resuelta la diferencia constructiva, en materiales y técnicas, existente entre la cabecera, incluidos los extremos del crucero, y el resto de los paramentos laterales y del cierre de los pies del edificio. No hay indicios de que se produjera una interrupción temporal durante la construcción, y menos aún, de que los últimos estén sustituyendo a otros paramentos desaparecidos. En este sentido se ha podido comprobar que el muro del lado sur 
apoya directamente sobre la roca, sin rastros de otros cimientos anteriores, y que el adosamiento entre él mismo y el del crucero, en función de la disposición que presenta la solución de continuidad que interrumpe el último, parece responder igualmente a un planteamiento inicial. $\mathrm{Al}$ mismo sentido de continuidad de obra apunta la presencia de sillares del mismo tipo en las puertas norte y sur, en el recercado original de la ventana de los pies, y en la pilastra de entrega de la arcada del lado sur. Así como el uso de sillares encadenados en la esquina suroeste. El motivo en el cambio de materiales en las naves pudo estar relacionado con un ahorro de costes, ya que al estar la roca más alta era menos necesario un cimiento potente, y por tanto era posible utilizar una mampostería más sencilla. Este ahorro cabe a su vez relacionarlo con quienes y cuando promovieron y financiaron la obra.

De forma simultánea, la investigación también debía tratar de establecer su cronología, quién promovió su construcción y a que maestro o maestros de obras puede atribuirse la misma. Ya hemos discutido estos problemas. Resumiendo lo expuesto, no puede descartarse la edificación de dos iglesias realizadas sucesivamente por el arzobispado de Toledo, aunque en estos momentos, a la luz de los datos, no hay que descartar que este hubiese iniciado o construido la iglesia de La Concepción, mientras que la necesidad de justificar la posesión del Adelantamiento de Cazorla llevó a D. Francisco de los Cobos, o a sus sucesores, a construir la de Santo Domingo, al mismo tiempo que en la vecina Cazorla levantaban la de Santa María.

Otra cuestión, sólo tangencialmente ligada a la anterior, es la de la autoría de los proyectos y la ejecución de estas iglesias. Del mismo modo que no hay documentación sobre el promotor, falta igualmente sobre quienes las ejecutaron. La pobreza de la de Santo Domingo hace pensar a Chueca Goitia, Pedro Galera, etc. que se trata de una obra realizada por canteros de la zona, aunque pudo estar supervisada por un maestro de mayor categoría que, en parte, realizaría las trazas de la cabecera. A este respecto hasta ahora se ha citado a Andrés de Vandelvira y a Rodrigo de Gibaja, ya que en la iglesia hay elementos empleados frecuentemente por ambos. Así mismo se ha atribuido su conclusión, a partir de 1589, a Gabriel Ruiz de Tauste (Mendoza et alii 2005:488), aunque sin citar documentos al respecto.

3. Por lo que se refiere al tercer periodo, cuando se instala en este edificio el cementerio municipal en el siglo XIX, hay que tener en cuenta que la intervención de los ayuntamientos o concejos municipales en este campo estuvo siempre mediatizada por la autonomía de las iglesias. En los últimos siglos medievales convivieron varias tradiciones en relación a los enterramientos, realizándose estos tanto en las iglesias o en sus anejos, como en cementerios exteriores a las poblaciones. No obstante, a partir del siglo XVI, con el fin de controlar a los conversos (judíos y musulmanes) se hizo obligatoria la inhumación en las iglesias, y el tema pasó a la jurisdicción eclesiástica, quedando fuera del control del gobierno, según exponía Jovellanos (1956). Aunque cuando surgían problemas, era el concejo municipal quién debía buscar soluciones, como sucedió en Baza, donde las iglesias y monasterios se negaron a aceptar el enterramiento de conversos, y fue el concejo municipal quién debió solucionar el problema, buscando un lugar adecuado (Gallego Burín y Gamir Sandoval 1996:134-135).

A finales del siglo XVII empezó a ser un grave problema la saturación que registraban muchas iglesias y cementerios parroquiales. Al mismo tiempo, se extendió una progresiva conciencia, impulsada por los ilustrados del siglo XVIII en toda Europa, acerca de lo insalubre que resultaba la inhumación en las iglesias urbanas. Esta preocupación llegó también a España (Ponz 1988:47-48; Jovellanos 1956) y culminó en la Real Cédula de 3 de abril de 1787 , por la que Carlos III ordenaba que se establecieran cementerios fuera de las poblaciones. Carlos Saguar (1988) indica que el desencadenante de la ordenanza fue la epidemia de Pasajes de 1781, entre cuyas causas se encontraba, según algunos testimonios, el fedor intolerable que exhalaba la parroquia, por los muchos cadáveres sepultados alli. Por su parte Francisco Javier Rodríguez (1996: 18-19) indica que la ordenanza se apoyaba en las Partidas de Alfonso X para poder combatir la oposición de los sectores tradicionalistas, y la misma suponía recuperar para el gobierno un tema que, como se ha señalado, había pasado a la jurisdicción eclesiástica.

Aunque en Andalucía no parece que la ordenanza se cumpliera, al menos hasta la epidemia de peste amarilla de 1800, la misma implicaba que los ayuntamientos debían intervenir para proporcionar espacios de enterramiento. Quizá ello explique que, en numerosas ocasiones, entre los siglos XVIII y XIX, ante la falta de espacios, para éstos fuera una opción razonable la reutilización de edificios en ruinas o que habían perdido su uso, como iglesias o castillos, que disponían de espacios suficientemente amplios para cumplir dichas funciones, y que por diversas circunstancias habían pasado a manos municipales, o que era razonable utilizarlos con esta finalidad. En el Alto Guadalquivir se han documentado un buen número de ellos. Entre las iglesias 
cabe recordar la reutilización de la iglesia de Santa María de Cazorla, muy próxima a La Iruela, y destruida en parte durante una crecida del arroyo Cerezuelo el 2 de junio de 1694, sobre el que estaba construida (Galera 2000a:9394), y que fue empleada como cementerio hasta el siglo XX, según ha demostrado la reciente intervención de restauración realizada durante 2008. Entre los castillos, podrían citarse el de las Torres Oscuras de Torreperogil (Castillo, Castillo 1992; Castillo, Castillo, Marín 1992), que probablemente se empezó a utilizar como cementerio ya a finales del XVII y que se clausuró como tal en 1819; o el de Baños de la Encina que se clausuró en 1828, y cuyos últimos enterramientos fueron retirados durante las excavaciones de 2007-2008. En la ciudad de Jaén se utilizó como cementerio durante parte del siglo XVIII la huerta del abandonado convento de los Capuchinos, hasta que se construyó el nuevo en 1829 (Madoz 1988:164). La retirada de los restos inhumados en la mayoría de estos cementerios se llevó a cabo siguiendo patrones semejantes. Esto es, traslado a los nuevos cementerios de los restos de quienes habían sido inhumados en nichos, dejando gran parte de las inhumaciones en el suelo in situ. La recuperación de estos edificios está llevando en los últimos años a retirar dichas inhumaciones en el curso de excavaciones arqueológicas.

El uso de la iglesia de Santo Domingo de La Iruela como cementerio municipal parece responder a este patrón, aunque la principal novedad quizá sea lo tarde que se produce el fenómeno. Quizá el motivo sea que, en realidad, se había continuado enterrando en la misma hasta su abandono por ruina, y que no se había llegado a la colmatación de la misma, dado lo relativamente reducido de la población del lugar. La reorganización de la iglesia como cementerio municipal debió ser por ello relativamente fácil, ya que probablemente sólo implicó la construcción de numerosos nichos en tres de sus frentes, mientras siguió enterrándose en el interior y en el espacio situado al este de la misma. A que se emplease con esta finalidad ayudó también su posición relativamente marginal respecto al centro de la población.

El proceso de recuperación actual, financiado por la Junta de Andalucía y la Diputación Provincial de Jaén, se propone el saneamiento, la consolidación de los restos que aún quedan del edificio, y la recuperación de su historia.

\section{Bibliografía}

Azuar Ruiz, R. (2005): «Aspectos simbólicos de la arquitectura militar almohade. El falso despiece de sillería y las bóvedas de arcos entrecruzados». En P. Cressier, M. Fierro y L. Molina (editores): Los almohades: problemas y perspectivas, vol. I, pp. 123-147.
Bazzana, A.; Cressier, P.; Guichard, P. (1988): Les châteaux ruraux d'al-Andalus. Histoire et archêologie des husun du sud-est de l'Espagne. Madrid.

Carriazo Arroquia, J. de M. (1975): Colección Diplomática de Quesada, Jaén.

Castillo Armenteros, JC.; Castillo Armenteros, JL. (1992): «Intervención arqueológica de urgencia en las Torres Oscuras de Torreperogil (Jaén)». Anuario Arqueológico de Andalucía 1990, vol. III Actividades de Urgencia. Sevilla, pp. 265-272.

Castillo Armenteros, JC.; Castillo Armenteros, JL.; Marín García, Ma del M. (1992): «Segunda fase de intervención arqueológica de emergencia en las Torres Oscuras de Torreperogil (Jaén)». Anuario Arqueológico de Andalucía 1990, vol. III Actividades de Urgencia. Sevilla, pp. 273-279.

Chueca Goitia, F. (1971): Andrés de Vandelvira arquitecto, Jaén.

Eslava Galán, J. (1999): Los castillos de Jaén. Jaén.

Fernández Serdán, J.M. (redactor doc. original) (2001): Análisis urbanistico de Centros Históricos de Andalucía: ciudades medias y pequeñas. Sevilla.

Galera Andreu, P. (2000a): Andrés de Vandelvira. Madrid.

Galera Andreu, P. (2000b): «El Renacimiento en el Alto Guadalquivir», en De la Edad Media al Siglo XVI, Jaén, pp. 295-302.

Galera Andreu, P. (2007): "Andrés de Vandelvira en Jaén» en Vandelvira, renacimieto del sur. Exposición 500 aniversario Jaén 2008. Jaén, pp. 15-37.

Gallego Burín, A. y Gámir Sandoval, A. (1996): Los moriscos del Reino de Granada según el Sinodo de Guadix de 1554., Granada. (Ed facsimil de la preparada por Fr Darío Cabanelas Rodriguez, o.f.m., Granada 1968).

García Guzmán, Ma del M. (1985). El Adelantamiento de Cazorla en la Edad Media. Cádiz.

García Guzmán, Ma del M. (1991): Colección diplomática del Adelantamiento de Cazorla (1231-1495). Cádiz.

Gila Medina, L.; Ruiz Puentes, V.M. (1992): «Andrés de Vandelvira, aproximación a su vida y obra». Arquitectura del renacimiento en Andalucía. Andrés de Vandelvira y su época. Exposición, pp. 81-118.

González, J. (1983): Reinado y diplomas de Fernando III, Diplomas II (12171232). Córdoba.

Gurriarán Daza, P.; Sáez Rodríguez, A.J. (2002): «Tapial o fábricas encofradas en recintos urbanos andalusíes», II Congreso Internacional La ciudad en alAndalus y el Magreb, pp. 561-625.

Henares Cuellar, I. (1992): «Reforma religiosa y utopia política en el renacimiento andaluz» en Arquitectura del renacimiento en Andalucía. Andrés de Vandelvira y su época, Sevilla, pp. 53-77.

Jovellanos, M.G. de (1956): «Reflexiones sobre la legislación de España en cuanto al uso de las sepulturas». Biblioteca de Autores Españoles, vol. 87, Madrid, pp. 75-105.

Keniston, H. (1980): Francisco de los Cobos secretario de Carlos V. Ed. Castalia. Madrid.

Madoz, P. (1988): Diccionario geográfico-estadístico-histórico de España y sus propiedades de ultramar, Madrid 1845-1850. Facsimil Jaén, Barcelona.

Magaña Bisbal, L. (1954): "Alonso de Covarrubias y la Iglesia Mayor de Baeza», Archivo Español de Arte, vol. XXVII, pp. 35-45.

Márquez Bueno, S.; Gurriarán Daza, P. (2008): «Recursos formales y constructivos en la arquitectura militar almohade de Al-Andalus». Arqueología de la Arquitectura, vol. 5, pp. 115-134.

Moliniè-Bertrand, A. (1977): «El adelantamiento de Cazorla en el siglo XVI. Análisis de las estructuras sociales y de ciertos aspectos de la economía de aquella parte meridional de Castilla». Cuadernos de investigación histórica, núm.1, pp. 7-22.

Montero Fernández, F. J.; Olmedo Granados, F.; Oporto Navajas, Ma J.; Regidor Jiménez, Ma I. (1991): Positos, cillas y tercias de Andalucía, Sevilla.

Moreno Mendoza, A.; Almansa Moreno, J. M.; Jodar Mena, M. (2005): Guía artística de Jaén y su provincia, Sevilla.

Navarro Pérez, M.; Gutiérrez Calderón, Ma V. (en prensa): «La fortaleza de La Iruela, la cultura material antes y después de la conquista» en Miradas Cruzadas. Las Navas de Tolosa 1212-2012. Jaén.

Polaino Ortega, L. (1956): «Unas ordenanzas de la villa de La Iruela, de fines del siglo XV». Boletín del Instituto de Estudios Giennenses, 10, pp. 73-95

Ponz, A. (1988): Viaje de España, tomo 2, Madrid. (Ed. facsimil del tomo V de la edición de 1776, Madrid.) tomo XIV. Madrid.

Olivares Barragán, F. (1987): Jaén y sus cien pueblos. Jaén. 
Primera Crónica General de España (1977). Ed. Ramón Menéndez Pidal (3a reimpr.), Madrid.

Rivera Recio (1948): El Adelantamiento de Cazorla. Toledo.

Rodríguez Barberán, F.J. (1996): Los cementerios de la Sevilla contemporánea. Análisis histórico y artístico (1800-1950). Sevilla.

Rubio Lapaz, J. (1990): «Análisis de la obra de Rodrigo de Gibaja, Arquitecto del siglo XVI». Cuadernos de Arte de la Universidad de Granada, vol. 21, pp. 135161.

Ruiz Calvente, M. (2007): «Eje cronológico» en Vandelvira renacimiento del sur. Exposición 500 aniversario Jaén 2008. Jaén, pp. 193-228.

Rus Puerta, F. (1998): Corografía antigua y moderna del Reino y Obispado de Jaén, Jaén. Estudio preliminar, revisión e índices: José Latorre García, Jesús Cañones y Juan A. López Cordero. UNED, Jaén, p. 146. Edición faccisimil de la de 1898, realizada por la Real Sociedad Económica de Amigos del País de Jaén, en base a la copia del manuscrito de 1646 realizado para el P. Flores.
Saguar Quer, C. (1988): "Carlos III y el restablecimiento de los cementerios fuera de poblado", en Fragmentos, Madrid, no 12-13-14, 1988, pp. 240-259.

Salvatierra Cuenca, V. (2006): «El castillo de La Iruela (Jaén)». Arqueología y Territorio Medieval, vol. 13-2, Jaén, pp. 67-125.

Salvatierra Cuenca, V. (en prensa): «Excavaciones arqueológicas en la fortaleza de La Iruela (Jaén)». Anuario Arqueológico de Andalucía. Sevilla.

Salvatierra Cuenca, V.; Castillo Armenteros, JC.; Gómez Cabeza, F.; Visedo Jiménez A. (2006): "Evolución en la ocupación de un territorio en época medieval. El valle de Hornos-Trujala (segura de la Sierra, Jaén)", en Proyectos de Investigación 2004-2005, pp. 7-82.

Ximenes Paton, B. (1983): Historia de la antigua y continuada nobleza de la ciudad de Jaén, Jaén. Edición faccisimil de la de 1628.

Ximénez de Rada, R. (1989): Historia de los hechos de España. Introducción, traducción, notas e índices de Juan Fernández Valverde. Alianza editorial, Madrid.

Recibido: 22 de noviembre de 2011 Aceptado: 30 de mayo de 2012 